\title{
Making Constitutional Doctrine in a Realist Age
}

Victoria Nourse

Georgetown Law Center, vfn@law.georgetown.edu

Georgetown Public Law and Legal Theory Research Paper No. 12-107

This paper can be downloaded free of charge from:

https://scholarship.law.georgetown.edu/facpub/1001

http://ssrn.com/abstract=2115636

145 U. Pa. L. Rev. 1401-1457 (1997)

This open-access article is brought to you by the Georgetown Law Library. Posted with permission of the author. Follow this and additional works at: https://scholarship.law.georgetown.edu/facpub


Commons, and the Jurisprudence Commons 


\section{University of Pennsylvania Law Review}

FOUNDED 1852

Formerly

American Law Register

\section{ARTICLES}

\section{MAKING CONSTITUTIONAL DOCTRINE IN A REALIST AGE}

\section{VICTORIA F. NOURSE ${ }^{\dagger}$}

How is constitutional doctrine made? Why do some words emerge as constitutional necessities while others fade from memory? Even if we assume that all doctrine is and will continue to be formal, why do courts choose the formalisms that they do? To these large questions, there are no simple answers. Constitutional doctrine spills from the pages of the federal reporters every day, covering oceans of subject matter so vast that no single theory could possibly navigate it all. And, yet, scholars have been trying of late to articulate theories of

† Assistant Professor of Law, University of Maryland; Assistant Professor of Law, University of Wisconsin. B.A. Stanford University; J.D. University of California (Boalt Hall). Many thanks to those who have read and talked with me about this Article, including Ann Althouse, Rick Cudahy, Deborah Hellman, Neil Komesar, Peter Quint, Jane Schacter, and Jana Singer. I am particularly grateful to those who listened to an early version of one portion of this paper at a faculty workshop at the University of Wisconsin and whose many questions induced me to continue struggling with these ideas. All errors and failures of articulation are, of course, my own. 
the modern doctrinal enterprise. From right, left, and in between, they have recently joined hands to warn us of a "new formalism": that, for better or worse, doctrine is becoming more, rather than less, formal and, as a result, less accessible to the people. ${ }^{1}$

This focus on the "new formalism" leaves a number of questions unanswered about why we choose the doctrinal vocabularies that we do. Consider a court that creates a new doctrinal rule by focusing on a "clear and compelling interest" or the "reasonable expectations" of the parties. ${ }^{2}$ The court is not trying to be more formalistic or obscure; indeed, the court is unlikely to be conscious of its doctrinal art. Judges are too busy relying upon these terms to assume anything but that doctrine may be made this way-that it is appropriate to focus upon "interests" rather than "claims," or that there is great significance in choosing the adjective "compelling" rather than "substantial." Even if unconscious, these moves are nevertheless of extraordinary importance. And perhaps because of their importance, we find it difficult to remind ourselves that we are leaning upon something contingent ${ }^{3}-$ that if the law books of the past fifty years

'See Daniel A. Farber, Missing the "Play of Intelligence", 36 WM. \& MARY L. REV. 147, 149 (1994) (decrying the increasing "bureaucratic" flavor of Supreme Court writing); $\rightarrow$ Morton J. Horwitz, The Supreme Court, 1992 Term-Foreword: The Constitution of Change: Legal Fundamentality Without Fundamentalism, 107 HARV. L. REV. 30, 98 (1993) (describing the Court as "trapped in the grips of mechanical jurisprudence"); Michael Stokes Paulsen, Captain James T. Kirk and the Enterprise of Constitutional Interpretation: Some Modest Proposals from the Twenty-Third Century, 59 ALB. L. REV. 671, 674-76 (1995) ("The Supreme Court's present style of constitutional discourse is the practical equivalent ... of the Yangs' inarticulate grunts. $\rightarrow$ Richard A. Posner, Judges' Writing Styles (And Do They Matter?), 62 U. CHI. L. REV. 1421, 1442-43 (1995) (criticizing the "pure" style of opinion writing, with its multi-factor tests, as retarding the search for real meaning); see also ROBERT F. NAGEL, CONSTITUTIONAL CULTURES: THE MENTALITY AND CONSEQUENCES OF JUDICIAL REVIEW 121-55 (1989) (arguing that modern constitutional doctrine is "formulaic"). But $\rightarrow$ Frederick Schauer, Opinions as Rules, $62 \mathrm{U}$. CHI. L. REV. 1455, 1456-59 (1995) (agreeing with Professors Farber, Horwitz, and Nagel that Supreme Court opinions have developed a bureaucratic, formulaic style, but arguing that there is nothing particularly unfortunate about this).

${ }^{2}$ See, e.g., Employment Div. v. Smith, 494 U.S. 872, 895 (1990) (O'Connor, J., concurring in judgment) (describing the "compelling interest" test in religion clause cases as barring "encroachments upon [religious] liberty, whether direct or indirect, unless required by clear and compelling governmental interests" (citation omitted)); Katz v. United States, 389 U.S. 347, 360-61 (1967) (Harlan, J., concurring) (focusing the question of whether there is a "search" under the Fourth Amendment on a reasonable person's "expectation" of privacy).

${ }^{3}$ Cf. Ludwig WitTGenstein, ON CERTAinTy 12e-14e (G.E.M. Anscombe \& G.H. von Wright eds., Denis Paul \& G.E.M. Anscombe trans., 1969) (noting the error of saying that we have a belief that the world started more than five minutes ago, a matter 
were destroyed by cataclysm or fire, many of our most revered constitutional concepts would be gone.

Why is it that, if Justice Holmes were resurrected tomorrow, he would need a translator of sorts to explain the new world of constitutional tests and factors and scrutinies? Would it be enough to explain that doctrine had simply become "formulaic" or "bureaucratic" or "methodologically obsessed"? ${ }^{4}$ In what follows, I consider a different hypothesis: Doctrine is not simply random wordchoice, but reflected job description. If doctrine has changed, it has changed because the modern Court sees its institutional strengths and weaknesses differently than it did in an earlier era. After a century spent debunking the common law ideal ${ }^{5}$ in the name of "realism," it would be odd, indeed, if modern constitutional doctrine

on which few will have formulated a belief, not because the fact is doubted, but because we are too busy relying upon it to go about doubting it).

${ }^{4}$ See, e.g., NAGEL, supra note 1 , at 128 (describing the modern formulaic style as "an amalgam of the bureaucratic and the academic"); Farber, supra note 1, at 150-52 (describing the bureaucratic features of modern constitutional doctrine); Horwitz, supra note 1, at 98-99 (arguing that contemporary Supreme Court opinions are dense with various "methodological obsessions").

See ANTHONY T. KRONMAN, The LOST LAWYER: FAILING IdeAlS OF the Legal PROFESSION 21, 165, 170-225 (1993) (recounting the sea change over the century in the ideas "taught in [law] schools, practiced in [law] firms, and made by judges in courts" away from a pragmatic program that viewed the work "of lawyers through the prism of the common law"); see also GRANT GILMORE, THE AGES OF AMERICAN LAW 104 (1977) ("In the 1970s we look back on an unpleasant half century which has been largely devoted to destroying the illusions which had commended themselves to the men of the 1870s.").

"Let me emphasize at the outset that I am using the term "realism" in its popularized sense. By that, I refer to a set of ideas that have filtered through legal education as "realism," however crude or naive these ideas may seem when compared to the actual historical record. On realism generally and its influence on legal thought and education, see AMERICAN LEgAL REALISM 49 (William W. Fisher III et al. eds., 1993) (compiling and summarizing selected original sources viewed today as essential to the Realist movement); NEIL DUXBURY, PATTERNS OF AMERICAN JURISPRUDENCE 65-159, 65 (1995) ("American legal realism is one of the great paradoxes of modern jurisprudence. No other jurisprudential tendency of the twentieth century has exerted such a powerful influence on legal thinking while remaining so ambiguous, unsettled and undefined."); MORTON J. HORWITZ, THE TRANSFORMATION OF AMERICAN LAW 18701960: THE CRISIS OF LEGAL ORTHODOXY 169-268 (1992) ("The most important legacy of Realism . . . was its challenge to the orthodox claim that legal thought was separate and autonomous from moral and political discourse."); LAURA KALMAN, LEGAL REALISM AT YALE 1927-1960, at 3, 33-34 (1986) ("The [legal] realists pointed to the role of human idiosyncracy in legal decision making, stressed the uselessness of legal rules and concepts, and emphasized the importance of greater efficiency and certainty in law administration."); and KRONMAN, supra note 5, at 185-225 (stating that "[w]hat the realists all opposed was the conception of legal science that Langdell had offered as a 
had not become self-conscious of the possibility of doctrinal failure. What has gone unnoticed, however, is how courts' new selfconsciousness has influenced constitutional doctrine itself-how courts' embrace of the scrutiny of interests rather than the assertion of powers, their fondness for methodological queries rather than seriatim citation, reflects a peculiarly modern ${ }^{7}$ institutional self-doubt. In other words, our answer to the resurrected Justice Holmes may be that doctrinal rhetoric has changed, at least in part, because this century has witnessed a revolution in courts' image of themselves and of doctrine itself.

In what follows, I consider three examples of modern constitutional doctrine that show how judges have stolen bits and pieces from popularized skepticisms about the job of judging and have molded this stolen rhetoric into doctrine. In the first example, I ask whether constitutional law's recent penchant for doctrinal rules based on "clear law" could have existed without the modern age's obsession with legal uncertainty. ${ }^{8}$ In the second, I consider whether our contemporary rhetoric of constitutional "interests" and "expectations" reflects modern critiques of doctrine as failing to address social needs. ${ }^{9}$ In the third, I ask how an offhand reference to the term "fundamental" could come to describe a legal category defined by courts' own fears of illegitimacy except in an age selfconscious of the judiciary's institutional weaknesses. ${ }^{10}$ If I am right about these examples, it may be that what was once said of modern painting's abstraction-that whatever else it was about, it was “"about painting"," -is true of modern doctrine's abstraction as well: that it

model for the work of the new law school professoriate that he himself did so much to create").

${ }^{7}$ I use the term "modern" despite our advancement to a postmodern age since I believe that the doctrinal institution's sense of legitimacy hails from a period earlier than our own, a period in which judges of the post-war period received their legal education. See GILMORE, supra note 5, at 87 ("And it should be borne in mind that what is taught in the law schools in one generation will be widely believed by the bar in the following generation.").

${ }^{8}$ See infra Part II (discussing the development of rules governing constitutional remedies that require courts to dismiss the constitutional claim if the right claimed is not "clearly established").

"See infra Part III (discussing doctrinal rules that depend upon the "expectations" or "interests" of the parties).

${ }^{10}$ See infra Part IV (discussing contemporary readings of Skinner v. Oklahoma, 316 U.S. 535 (1942)).

$\rightarrow$ David Luban, Legal Modernism, 84 MICH. L. REV. 1656, 1661 (1986) (quoting Stanley CaVell, Music Discomposed, in MUSt We MEAN What We SAY? 207 (1969)) 
is about doctrine and doctrine's struggle in an age self-conscious of the possibility of doctrinal failure.

Obviously, these three examples cannot prove that doctrinal rhetoric reflects a history of shifting institutional ideals or that doctrine has absorbed a kind of institutional self-criticism. But as long as theories are being constructed, ${ }^{12}$ I think it is worth considering an approach that neither romanticizes past ages nor repeats familiar criticisms. ${ }^{13}$ Modern constitutional doctrine presents an important question of collective action: How do large groups of people end up speaking the same constitutional language when that language changes over time? One plausible answer is that doctrine is a practice that develops within institutions, not simply as the random acts of individual judges. ${ }^{14}$ Indeed, those who study institutions from a distance have long understood that institutions are maintained, over time, by squeezing ideas into a common shape, a shape that carries forward, unacknowledged, an ideal picture of the institution. ${ }^{15}$ These ideals become the default image, sustaining the institution's perceived identity relative to other institutions. When those images are challenged, the institution uses its traditional methods (here, the doctrinal category) to tame the critique, but, in doing so, recapitulates the institutional challenge (here, within the doctrine created).

In Part I, I set my position in context, surveying briefly those who have tried to capture modern doctrinal practice in larger constitutional frames. In Parts II, III, and IV, I recount three different doctrinal histories, arguing that each has been fundamentally shaped by courts' self-consciousness of the failures of a

12 See supra note 1.

13 See infra Part I (arguing that many contemporary complaints about "formulaic" doctrine repeat arguments made at the beginning of the century by the realists).

${ }^{14}$ See Edward Rubin \& Malcolm Feeley, Creating Legal Doctrine, 69 S. CAL. L. REV. 1989, 2030 (1996) ("[J]urisprudence tends to speak of 'the judge,' as if America had only one of them, operating in lordly isolation."); see also PHILIP BOBBITT, CONSTITUTIONAL INTERPRETATION 163-70, 179 (1991) (arguing that constraints on judging emanate from rules of practice shared by the judiciary as a whole).

${ }^{15}$ See Mary Douglas, How InStitutions Think 55 (1986) (“[F]or discourse to be possible at all, the basic categories have to be agreed on. Nothing else but institutions can define sameness. Similarity is an institution. Elements get assigned to sets where institutions find their own analogies in nature."); see also MARTHA MINOW, MAKING ALL THE DIFFERENCE: INCLUSION, EXCLUSION, AND AMERICAN LAW 79-80 (1990) (agreeing with Douglas that "[i]nstitutions establish what count as correct and incorrect patterns of thought"). 
common law ideal of judging. ${ }^{16}$ As the histories show, by doctrinalizing the critique (for example, by cabining the critique of indeterminacy in a rule that depends upon finding "unclear law"), this method accomplishes two seemingly incompatible ends: Doctrine (1) acknowledges critique; and (2) cabins it within categorical boundaries, leaving a place, outside those boundaries, where older ideals may flourish (where law is indeed "clear"). The result is that, when we go to draw the doctrinal lines, we find ourselves enmeshed in difficult questions of institutional identity (to apply the "clear law" rule, for example, we end up having to decide what counts as "law"17). I conclude in Part V by suggesting that, if doctrinal practice ${ }^{18}$ operates like other social institutions, we should expect to see doctrine trying to respond to its critics, including the "realist" ones, ${ }^{19}$ even if this effort recapitulates familiar struggles. ${ }^{20}$ If there is a certain inevitability to all this, there are also obvious dangers. Cases themselves cannot be skeptical; inevitably, courts

${ }^{16}$ Only in the past few years have scholars attempted to reverse the century's hostility toward common law decisionmaking ideals in constitutional law. See CASS R. SunSteIn, LeGAl REASONING AND POLITICAL CONFLICT 77-79 (1996) ("To the extent that the common law generally respects freedom of contract, private property, and private ordering, it has many virtues from the standpoint of efficiency. Common law judgments also reflect intelligible understandings of liberty. $\rightarrow$ David A. Strauss, Common Law Constitutional Interpretation, 63 U. CHI. L. REV. 877 (1996) (promoting the common law approach to understanding American constitutional law).

${ }^{17}$ See infra Part II (discussing issues raised by the "clear law" rule).

${ }^{18}$ What I mean by "practice" is simply that doctrine is something that people "do" as well as a set of directives or rules. And, as something that people "do," doctrine (like any other practice) is subject to the incentives and limits of the institutional structures in which it is created, structures that reflect both the nature of courts (doctrine's site) relative to other institutions, as well as influences from other, less formal, legal institutions such as the academy (doctrine's antagonist). See infra Part V. To see that doctrine is itself an institution acknowledges the ultimate power of the three principal decisionmaking institutions (courts, legislatures, and administration) to shape legal culture, but it rejects the notion that we have three, and only three, legal institutions worth studying.

${ }^{19}$ I do not say this to blame theory, or realism, for doctrine's failures. (To the extent my own work relies on empirical analysis $\rightarrow$ : Victoria Nourse, Passion's Progress: Modern Law Reform and the Provocation Defense, 106 YALE L.J. 1331 (1997), it falls in a direct line from realist premises.) I say it to try to give new life to something that Karl Llewellyn once wisely insisted upon-an understanding of law as an institution. See

$\rightarrow$ Karl N. Llewellyn, The Constitution as an Institution, 34 COLUM. L. REV. 1, 17 (1934) ("Every living constitution is an institution ....").

${ }^{20}$ As Mary Douglas has explained, when we choose particular concepts, we are "also picking and choosing at the same time their allies and opponents and the pattern of their future relations," a process that tends to cause arguments to repeat themselves in different rhetorical guises. DOUGLAS, supra note 15, at 63. 
decide. $^{21} \quad$ A court that truly seeks to incorporate this century's "realism"-that assumes all doctrine is uncertain or relative-cannot decide. A court that tames some popular critiques by putting conceptual edges around them (for example, by turning indeterminacy into a doctrinal search for "unclear" law) may still come to a resolution, but stops along the way to engage in a battle about its own image that may be unnecessary and divertingly selfinvolved. The danger here is that a court will mistake its own institutional struggles for the real-life struggles of the litigants before it, replacing the nineteenth century's constitutional arrogance with a modern constitutional narcissism.

\section{STUDYING MODERN CONSTITUTIONAL DOCTRINE}

Contemporary scholarship has devoted little effort to considering the ways courts make constitutional doctrine. If we put to the side, for the moment, normative critiques of particular doctrines ${ }^{22}$ and focus on efforts to take a more general view, three approaches stand out. First, there are those who have sought to identify a modern style of opinionwriting, and whose efforts have been largely, although not uniformly, critical of an increasingly "formulaic" doctrine. ${ }^{23}$ Second, there are those who have emphasized the Supreme Court's audience and, again, who have been largely critical of the ways in which modern constitutional doctrine excludes "we the people." ${ }^{24}$ Finally, there are those who have focused on constitutional rhetoric, arguing that the real object of study should be neither aesthetics nor audience, but rather the ways in which doctrine masks and shapes as it persuades. ${ }^{25}$ Unfortunately, although each of these approaches has something to say about how doctrine is made, none provides us with a ready answer as to why modern doctrine looks and feels "different"

${ }^{21}$ The "case" brings to bear pressures different in nature and kind from those brought to bear on the reasoning processes of markets, legislatures, or bureaucracies. See NEIL K. KOMESAR, IMPERFECT ALTERNATIVES 125-28 (1994) (comparing the institutional biases of markets, legislatures, and courts). It requires a decision. See BOBBITT, supra note 14, at 183 (noting that cases "require a decision, not a calculation or an interpretation, or even a passionate conviction").

${ }^{22}$ Some of these, of course, have been extraordinarily powerful. See, $e \rightarrow \mathrm{T}$. Alexander Aleinikoff, Constitutional Law in the Age of Balancing, 96 YALE L.J. 943, 943-44 (1987) (exploring and evaluating "a form of constitutional reasoning-balancingthat has become widespread, if not dominant, over the last four decades").

${ }^{23}$ See infra notes 27-35 and accompanying text.

${ }^{24}$ See infra notes 37-38 and accompanying text.

${ }^{25}$ See infra notes $42-48$ and accompanying text. 
from that of earlier eras. Indeed, each approach, in its own way, seems vaguely repetitive of arguments borrowed from an earlier era. ${ }^{26}$

\section{A. Style, Audience, Rhetoric}

To the extent scholars have tried to enumerate a modern constitutional style, ${ }^{27}$ they have focused on what Professor Nagel insightfully dubbed, almost a decade ago, the "formulaic constitution." 28 The idea that modern constitutional doctrine has acquired a peculiarly formalistic style was echoed in 1993 by Professor Horwitz in an incisive discussion of the Supreme Court's term, ${ }^{29}$ and again, recently, in elegant essays by Professor Farber, ${ }^{30}$ Professor Schauer, ${ }^{31}$ and Judge Posner. ${ }^{32}$ These scholars are surely right that part of the reason that modern doctrine looks and feels different is its layered reasoning style, ${ }^{33}$ with its dull penchant for what Professor

${ }^{26}$ Recently, Professors Rubin and Feeley have suggested a phenomenological approach to the "making" of doctrine which may prove a powerful new addition to the debate, but has yet to percolate through the academy. To some extent, my focus on institutions fits well with their approach, although my historical efforts are quite distinct from theirs. See Rubin \& Feeley, supra note 14, at 1991 (presenting a "theory of judicial lawmaking ... based upon phenomenology").

${ }^{27}$ Llewellyn seems to have been right when he cautioned that "' $[s]$ tyle' in analysis of great-institutions, is tricky. It needs vigilance lest it move into ... word-slinging." Karl N. Llewellyn, The Common law Tradition: Deciding Appeals 519 n.16 (1960).

${ }^{28}$ NAGEL, supra note 1 , at 121.

${ }^{29}$ See Horwitz, supra note 1, at 98 (“[M] ost of this Court's opinions ... [make] amazingly fine distinctions that produce multiple opinions designated in Parts, subparts, and sub-sub-parts ...."). But see Schauer, supra note 1, at 1459-66 (arguing against the idea that there is anything so terrible about opinions that bear such a "style").

${ }^{30}$ See Farber, supra note 1, at 150 ("Bluntly, much of what the Court produces these days lacks the qualities of good legal writing.").

${ }^{31}$ See Schauer, supra note 1, at 1457-59 (acknowledging the descriptive accuracy of claims concerning the "formulaic" style but arguing against the idea that such a style hinders constitutional decisionmaking).

${ }^{32}$ See Posner, supra note 1, at 1429-32 (concluding that most contemporary judicial opinions are in the "pure style," a style that is neither plain nor transparent, but artificial, technical, and impersonal).

${ }^{33}$ Much of the recent discussion on the "style" question, from both the left and the right, has focused on the "layered look" of modern constitutional doctrine. See, e.g., NAGEL, supra note 1, at 128 (arguing that the Court's formulae share characteristics of administrative rules and guidelines... [b]oth are complex, layered and equivocal"); Horwitz, supra note 1, at 98 (arguing that the Court's product has acquired a "thick undergrowth of technicality," "[w]ith three and four "prong' tests everywhere and for everything; with an almost medieval earnestness about 
Farber has termed the "inscrutable instructions" that typically accompany tax forms. ${ }^{34}$ Each author has provided a rich understanding of the aesthetics of modern opinionwriting in constitutional and other cases. On the other hand, identifying "formulas-as-formulas" as the distinctive feature of modern doctrine ${ }^{35}$ does not move us much beyond the realists' own screeds against formulaic conceptualism. ${ }^{36}$ After a century of doctrinal criticism, must our understanding stop with the notion that constitutional doctrine is "formulaic"?

Those seeking a modern constitutional style are not the only ones who have sought to examine doctrinal forms by taking a longer view. A number of scholars who otherwise share little in intellectual interest or temperament have suggested that we need to look at constitutional doctrine as a form of argument directed to particular audiences. ${ }^{37}$ Although reaching no uniform conclusion, some of the most incisive work argues that modern constitutional doctrine has little consciousness of its audience, and, as a result, fails to communicate an "intelligible constitution."

classification and categorization"); see also Farber, supra note 1, at 149 (echoing these concerns).

${ }^{34}$ Farber, supra note 1, at 152.

${ }^{35}$ See NAGEL, supra note 1, at 121 (arguing that "the formulaic style is one of the few basic fixtures" of modern constitutional doctrine).

${ }^{36}$ See, e.g., JEROME FRANK, LAW AND THE MODERN MIND 57 (1936) ("We lawyers are still held in the bonds of 'holy words' in the form of rules, principles, formulas and standards, reduced to well-polished phrases." (referring to the claims of Leon Green)); id. at 118 (decrying "the insistent effort to achieve predictability by the attempt to mechanize law, to reduce it to formulas $\rightarrow$ Karl N. Llewellyn, $A$ Realistic Jurisprudence-The Next Step, 30 Colum. L. REV. 431, 439 (1930) ("The statement 'this is the rule' typically means: 'I find this formula of words in authoritative books." "); see also HORWITZ, supra note 6, at 208 ("In much of the critical literature of Legal Realism, conceptualism is identified as the primary disease, accused of causing intellectual distortion in situations where there might otherwise be clear expressions of reality.").

${ }^{37}$ Emphasis on "audience" can be found in a variety of works, including those that emphasize the "formulaic" style or "rhetorical" approaches. See, e.g, NAGEL, supra note 1 , at 154-55 (arguing that the "formulaic" style tends to make the Court's work inaccessible to a public audience); JAMES BOYD WHITE, JUSTICE AS TRANSLATION at xiv, 11 (1990) (arguing that the law is a "branch of rhetoric" and, as a "professional discourse," has a "specialized audience" that shapes that rhetoric); see also Sanford Levinson, The Rhetoric of the Judicial Opinion, in LAW'S STORIES 187, 199-200 (Peter Brooks \& Paul Gewirtz eds., 1996) (arguing that Supreme Court Justices expect their opinions "to be read by multiple audiences").

${ }^{38}$ The phrase is Joseph Goldstein's in his book of the same title. See JOSEPH GoldSTEIN, THE INTELligible CONSTITUTION (1992); see also Burke Marshall, Foreword to THE INTELligible CONSTITUTION supra, at xvii ("Familiarity with the Court's work 
that modern doctrine bears the shopworn look of doctrine-by-order. But there is something less than satisfying about the claim that the "people are being left out" if we are trying to identify a distinctively modern doctrine. ${ }^{39}$ After all, would the average man on the street in 1935 have been any less bewildered when confronted with the idea of the "police power" than would a woman on the street in 1997 asked about the Edwards-Roberson standard? ${ }^{40}$ Again, we find ourselves making arguments that sound very much like the realists' derisive claims about "lawyers' language."

Finally, there are those who have chosen, quite rightly, to view doctrine with an emphasis on rhetorical understandings. ${ }^{42}$ Although this work is often illuminating, it is quite diverse, borrowing from a variety of traditions. ${ }^{43}$ Thus we learn that doctrine is constructed

overwhelmingly demonstrates at a minimum that the members of the Court view their work as directed at the elite, and not to the people.").

${ }^{39}$ I tend to agree with Professor Goldstein that we might have a better constitutional grammar if in fact the "people" felt as if they could participate in constitutional arguments, see GOLDSTEIN, supra note 38, at 6 ("If Ours is to be an 'intelligent democracy,' if Our revolutions are to be peaceful, We the People . . must be able to learn, from Our own reading of the Constitution and the Supreme Court's construction of it, what rights We have and do not have ...."), but I am notpersuaded that modern doctrine is any more inaccessible to the masses today than in earlier days or that, if it were, that would tell us much about why we create the doctrine that we do. See Schauer, supra note 1, at 1463 (noting that "ordinary people simply do not read judicial opinions").

${ }^{40}$ Butler v. McKellar, 494 U.S. 407, 412 (1990) (discussing Edwards-Roberson limitations, which limit police authority to interrogate a suspect once she has invoked the right to counsel).

${ }^{41}$ See FRANK, supra note 36, at 22-24 (using the layman's derisive attitude toward "lawyers' language" as part of his realist critique).

${ }_{42}$ I use "rhetorical understandings" here to encompass not only an aesthetic-as would a "style"-but also to encompass "reasoning" processes aimed at persuasion, whether that persuasion is defined politically or as a reflection of reason. See, $\rightarrow$ J.M. Balkin, Transcendental Deconstruction, Transcendent Justice, 92 MICH. L. REV. 1131, 1181 (1994) (discussing rhetoric as a form of "persuasive advocacy"); Posner, supra note 1, at 1422 (distinguishing rhetoric from style because rhetoric connotes a reasoning process aimed at persuasion).

${ }^{43}$ The diversity in the approaches is apparent from even a short list of those exploring law's rhetoric. See e.g., J.M. Balkin, A Night in the Topics: The Reason of Legal Rhetoric and the Rhetoric of Legal Reason, in LAW's STORIES, supra note 37, at 211, 216-18 (equating the semiotician's point that law consists of "standard pro and con responses" for every legal argument with the idea of "topics" in classical rhetoric); Lawrence Douglas, Constitutional Discourse and Its Discontents: An Essay on the Rhetoric of Judicial Review, in THE RHETORIC OF LAW 225, 227 (Austin Sarat \& Thomas R. Kearns eds., 1994) (arguing that constitutional interpretation reflects a rhetoric "of legitimation," in which "instabilities" of interpretation are "ceaselessly concealed and revealed, displaced and declaimed"); Reva B. Siegel, In the Eyes of the Law: Reflections on the Authority of Legal Discourse, in LAW's STORIES, supra note 37, at 225, 226 (exploring 
rather than given, malleable and obscuring rather than fixed and transparent, but we uncover few clues about why particular doctrines emerge, gain currency, and die. ${ }^{44}$ For example, in his essay The Law Wishes to Have a Formal Existence, Stanley Fish embraces doctrine's formal ingenuity, celebrating rather than decrying the ways in which law aspires to an autonomous existence distinct from morality or science. ${ }^{45}$ Rejecting the despairing conclusions of much critical scholarship, Fish argues that doctrine's failings and inconsistencies "enable[] law to work." Ultimately, however, this welcome contrarianism avoids the question I am trying to answer about the choice of particular doctrinal forms. At the end of the essay, Fish himself recognizes this, telling us that he has not "chart[ed] in any detail any of the differently contingent courses the law has taken in the areas it has marked out for its own." ${ }^{47}$ Thus, although his analysis may provide clues about doctrinal formulation at an abstract level, it avoids the particulars. In doing so, it leaves us wondering whether Fish's critique is simply an updated celebratory version of the old claim that law reflects the social and moral predilections of its authors, dressed up in fancy vocabularies. ${ }^{48}$

\section{B. Caveats}

Before I go any further, a few caveats are in order. Taking doctrine seriously poses several hazards of misunderstanding. ${ }^{49}$ To

rhetoric as the assertion of authority, the constituting of "our social universe through the language of the law" in the context of status discourse); see $\rightarrow$ James Boyd White, Law as Rhetoric, Rhetoric as Law: The Arts of Cultural and Communal Life, 52 U. CHI. L. REV. 684, 690-92 (1985) (emphasizing the ways in which legal language is a "constitutive rhetoric" creating a specific vision of "community").

${ }^{44}$ There are important exceptions, of course. See, $\mathrm{t} \rightarrow$ Reva B. Siegel, "The Rule of Love": Wife Beating as Prerogative and Privacy, 105 YALE L.J. 2117, 2117-21 (1996) (showing the "preservation through transformation" of a status regime in the history of doctrinal rules governing violence against women).

${ }^{45}$ See STANLEY FiSH, The Law Wishes to Have a Formal Existence, in THERE's No SuCH THING AS FREE SPEECH AND IT'S A GOOD THING, TOO 141 (1994).

${ }^{46}$ Id. at 169.

${ }^{47} I d$. at 178.

${ }^{48}$ See id. at 156 ("That is to say-and in so saying I rehearse the essence of my argument-the law is continually creating and recreating itself out of the very materials and forces it is obliged, by the very desire to be law, to push away.").

${ }^{49}$ One need only look at the pages of the leading law reviews to see evidence of "theory-orthodoxy." A LEXIS search for all articles published in the last decade that have the word "theory" in the title is incapable of completion because the search yields more than 1,000 documents. 
many in the academy, doctrine is an undifferentiated mass of rules similar in concept and uninteresting in detail. For them, the interesting question is, why formalism? $?^{50}$ On the opposite side of this divide sit practitioners and judges whose job descriptions compel them to focus on the question of "which" doctrine applies. ${ }^{51}$ In this Article, I ask a different question: why this doctrine as opposed to another? This assumes, of course, that doctrines have histories, that they emerge, gain currency, and may die. Although difficult to prove, this statement resonates with most lawyers' and academics' daily use and understanding of doctrine. ${ }^{52}$ It is also consistent with our understandings of law and language in general. Imagine, for example, that we could magically resurrect Justice Holmes and set him down with volume 483 of the United States Reports. We can be fairly sure that, as he flipped the pages, his brow might furrow upon

${ }^{50}$ The debate on such issues is so widely dispersed as to defy a footnote. However, for some interesting approaches, highlighting the differing uses of the term formalism, see Thomas C. Grey, Langdell's Orthodoxy, 45 U. PITT. L. REV. 1, 8 (1983) (“A legal system is formal to the extent that its outcomes are dictated by demonstrative (rationally compelling) reasoning."); Michael S. Moore, The Semantics of Judging, 54 S. CAL. L. REV. 151, 154 (1981) ("Formalism is essentially a theory of adjudication."); Richard A. Posner, Legal Formalism, Legal Realism, and the Interpretation of Statutes and the Constitution, 37 CASE W. RES. L. REV. 179, 181 (1986) ("Formalism enables a commentator to pronounce the outcome of the case as being correct or incorrect, in approximately the same way that the solution to a mathematical problem can be pronounced correct or incorrect. $\rightarrow$ Frederick Schauer, Formalism, 97 YALE L.J. 509, 510 (1988) ("At the heart of the word 'formalism,' in many of its numerous uses, lies the concept of decisionmaking according to rule."); and Ernest J. Weinrib, The Jurisprudence of Legal Formalism, 16 HARV. J.L. \& PUB. POL'Y 583, 583 (1993) ("Formalism is a theory of legal justification.").

${ }^{51}$ On the growing distance between academia and the bar, $\rightarrow$ Harry T. Edwards, The Growing Disjunction Between Legal Education and the Legal Profession, $91 \mathrm{MICH}$. L. REV. 34, 34-42 (1992) (bemoaning this growing distance). But $\rightarrow$ Richard A. Posner, The Deprofessionalization of Legal Teaching and Scholarship, 91 MICH. L. REV. 1921, 1921-28 (1993) (disagreeing with Edwards's views about contemporary legal scholarship).

${ }^{52}$ Scholars working from widely different positions have acknowledged the temporal dimensions of our categories, doctrinal and otherwise. See, $e \rightarrow$ Charles Fried, Constitutional Doctrine, 107 HARV. L. REV. 1140, 1152 (1994) (“[T]here are the rhythms and sequences by which doctrine... is brought into being, elaborated, modified, and perhaps eventually abandoned. $\rightarrow$ Robert W. Gordon, Critical Legal Histories, 36 STAN. L. REV. 57, 98 (1984) (“[T]he most elementary categories that people use to organize everyday life, are culturally and historically contingent; that is, they are specific to given places and times."); Duncan Kennedy, The Structure of Blackstone's Commentaries, 28 BUFF. L. REV. 205, 215-16 (1979) ("Categorical schemes have a life of their own."). 
encountering "quasi-suspect classes," "Witherspoon-excludable"54 jurors, and the "effects prong of the Lemon test." ${ }^{55}$ He might ask what happened to the "police power," "v6 "vested rights,"57 or "class legislation." ${ }^{58}$ Surely, however, he would recognize that law's working vocabulary, its language, and perhaps even its grammar, had changed.

${ }^{53}$ See, e.g., Bowen v. Gilliard, 483 U.S. 587, 602 (1987) (noting the Court's earlier rejection in Lyng $v$. Castillo, 477 U.S. 635, 638 (1986), of the notion that close relatives should be treated as a quasi-suspect class).

${ }^{54}$ See, e.g., Buchanan v. Kentucky, 483 U.S. 402,407 n.6, 415 (1987) (referring to jurors properly excluded under guidelines set out in Witherspoon v. Illinois, 391 U.S. 510 (1968)).

${ }^{55}$ See, e.g., Corporation of the Presiding Bishop of the Church of Jesus Christ of Latter-Day Saints v. Amos, 483 U.S. 327, 347 (1987) (O'Connor, J., concurring in judgment) (disagreeing with the Court's interpretation of the "effects' prong of the Lemon test").

${ }^{56}$ By the end of the nineteenth century, the "police power had become the standard legal category for talking about the state's regulatory power over the health, safety, and morals of its citizens." HORWITZ, supra note 6, at 27. For an overview of the development of the concept of the police power during the nineteenth century and up until 1934, see PAUl BREST \& SANFORd LEVINSON, PROCESSES OF CONSTITUTIONAL DECISIONMAKING 153-73, 285-300 (3d ed. 1992). For an in-depth analysis of the "police power" with a revisionist bent, see HOWARD GILlman, THE CONSTITUTION BESIEGED 61-146 (1993) (focusing on the Court's concern with "class" legislation in its police power decisions).

${ }^{57}$ During the first century of its development, "the core of general constitutional law was the vested rights doctrine." BREST \& LEVINSON, supra note 56, at 105-09, 291; see $\leftrightarrow \rightarrow$ Earl M. Maltz, Fourteenth Amendment Concepts in the Antebellum Era, 32 AM. J. LEGAL HIST. 305, 316-17 (1988) (discussing the concept of "vested rights").

58 "Class legislation" was a term of art used in late-nineteenth- and early-twentiethcentury opinions to refer to legislation that sought "to favor special interests at the expense of the public interest." HORWITZ, supra note 6, at 23; see GILLMAN, supra note 56, at 61-99 (redescribing pre-Lochner equal protection decisions in terms of the "class legislation" principle); see also, e.g., Barbier v. Connolly, 113 U.S. 27, 32 (1885) (stating that "class legislation, discriminating against some and favoring others, is prohibited" by the Fourteenth Amendment); The Civil Rights Cases, 109 U.S. 3, 24 (1883) ("What is called class legislation ... would be obnoxious to the prohibitions of the Fourteenth Amendment."). The idea of class legislation was incorporated into the basic standard governing the police power. See, e.g., Lawton v. Steele, 152 U.S. 133, 137 (1894) (noting that to justify the exercise of the police power, "it must appear ... that the interests of the public generally, as distinguished from those of a particular class, require such interference"). Such legislation was also deemed "partial." See, e.g., Minneapolis \& St. Louis Ry. Co. v. Beckwith, 129 U.S. 26, $28-29$ (1889) (noting that the Fourteenth Amendment "does undoubtedly prohibit discriminating and partial legislation by any State"). This principle appeared in constitutional law treatises as a viable category of constitutional law until at least 1929. 
Once we accept the notion that constitutional rhetoric has changed, it seems only right to consider why this might be so. ${ }^{59}$ Doctrine's sheer "ubiquity" has made its study difficult, but "underscores the need for a theory of its operation," as Professors Rubin and Feeley recently have suggested. ${ }^{60}$ At least in constitutional law, most have come to accept Philip Bobbitt's insight that there are different "forms" of argument and that "doctrinal argument" is one of those forms. ${ }^{61}$ A number of questions remain, however, about the ever-changing appearance of such arguments.

In what follows, I offer three case studies, intended less as the final word on doctrinal creation than as illuminating excerpts from a complex constitutional history. I proceed much the way an anthropologist or historian might-as if the entire doctrinal culture were strange to me, employing the device of a "foreign observer" to aid the investigation. ${ }^{62}$ In this world, the received wisdom about doctrine has disappeared and we are free to ask whether it might have been different. This stance helps to isolate the act of doctrinal creation from the substantive merits of the controversy, and at the same time allows the study of doctrinal formulations at work. I leave the world of "big" theory for one of "thick" description, of "local" knowledge of a doctrinal practice. ${ }^{63}$

${ }^{59}$ Even those scholars committed to the idea that doctrinal argument is "political" have their own stories about the history of doctrine. See, e.g., Gordon, supra note 52, at 116-25 (defending the historical study from a critical perspective).

${ }^{60}$ Rubin \& Feeley, supra note 14 , at 1990.

${ }^{61}$ PhILIP BOBBitT, CONSTITUTIONAL FATE 39-58 (1982) (describing and analyzing the doctrinal form of argument). But see J.M. Balkin \& Sanford Levinson, Constitutional Grammar, 72 TEX. L. REV. 1771, 1778 (1994) (acknowledging Bobbitt's grammar, but rejecting his distinction between "legitimacy and justification" as applied to that grammar).

${ }^{62}$ This approach is not standard doctrinal criticism, but neither is it unprecedented. See William Twining, Karl LleWEllyn AND tHE REalist MOVEMENT 250 (1973) (discussing Llewellyn's "claim[] that he read his samples of opinions in much the same way" that historians read historical documents).

${ }^{63}$ The terms "thick" and "local" are terms borrowed from anthropology which have found homes in legal scholarship as well. See, e.g., FISH, supra note 45, at 171 ("A rhetorical jurisprudence does not ask timeless questions; it inquiries [sic] into the local conditions of persuasion, into the reasons that work...."). On "local" knowledge as used in anthropology, see CLIFFORD GEERTZ, LOCAL KNOWLEDGE: FURTHER ESSAYS IN INTERPRETIVE ANTHROPOLOGY 215 (1983) ("Law . . . is local knowledge, local not just as to place, time, class, and variety of issue, but as to accent-vernacular characterizations of what happens connected to vernacular imaginings of what can."). 


\section{THE SEARCH FOR "CleAR LAW"}

If one is doubtful that modern constitutional doctrine has changed, one only has to look at the increasing incidence and importance of doctrinal rules that depend unashamedly upon the concept of legal "clarity" itself. It is no exaggeration to say that the Supreme Court has created so many doctrines requiring an inquiry about whether a right or power is "clear" or "unclear" that "commentators can [hardly] keep track of them." Today, "clear law" presents a threshold question in every constitutional tort case, ${ }^{65}$ many habeas corpus petitions, ${ }^{66}$ and some exclusionary rule claims. ${ }^{67}$ A similar emphasis on legal clarity now governs Tenth Amendment cases, ${ }^{68}$ Eleventh Amendment cases, ${ }^{69}$ as well as statutory interpretation $^{70}$ and administrative law cases. ${ }^{71}$ If, like the realists, we

${ }^{64}$ John Copeland Nagle, Waiving Sovereign Immunity in an Age of Clear Statement Rules, 1995 WIS. L. REV. 771, 771 (referring to "clear statement rules" in a variety of contexts); see $\rightarrow$ Richard H. Fallon, Jr. \& Daniel J. Meltzer, New Law, Non-Retroactivity, and Constitutional Remedies, 104 HARV. L. REV. 1733 (1991) (tracking a similar development of "clear law" rules in the context of constitutional remedies); Linda Ross Meyer, When Reasonable Minds Differ, 71 N.Y.U. L. REV. 1467 (1996) (analyzing clear law developments in qualified immunity and other contexts).

${ }^{65}$ See, e.g., Elder v. Holloway, 510 U.S. 510, 515 (1994) (applying clear law standard to $\S 1983$ claim against state official); Harlow v. Fitzgerald, 457 U.S. 800, 818 (1982) (holding that Bivens actions against federal officials are governed by the clear law standard).

${ }^{66}$ See, e.g., Teague v. Lane, 489 U.S. 288, 305-06 (1989) (stating that habeas petitioners may not rest claims upon "new rules"); Butler v. McKellar, 494 U.S. 407, 414 (1990) (interpreting Teague as saying that the "'new rule' principle ... validates reasonable, good-faith interpretations of existing precedents made by state courts even though they are shown to be contrary to later decisions").

${ }^{67}$ See, e.g., Illinois v. Krull, 480 U.S. 340, 355 (1987) ("Nor can a law enforcement officer be said to have acted in good-faith reliance upon a statue if its provisions are such that a reasonable officer should have known that the statute was unconstitutional.").

${ }^{68}$ See, e.g., Gregory v. Ashcroft, 501 U.S. 452, 464 (1991) ("Application of the plain statement rule thus may avoid a potential constitutional problem.").

${ }^{69}$ See, e.g., Blatchford v. Native Village of Noatak, 501 U.S. 775, 786 (1991) (stating that the power to abrogate Eleventh Amendment immunity "can only be exercised by a clear legislative statement"); Dellmuth v. Muth, 491 U.S. 223, 230 (1989) ("Lest Atascadero be thought to contain any ambiguity, we reaffirm today that in this area of the law, evidence of congressional intent must be both unequivocal and textual.").

${ }^{70}$ See, e.g., Beecham v. United States, 511 U.S. 368, 374 (1994) (announcing that the Court's task is "to determine whether the language the legislators actually enacted has a plain, unambiguous meaning").

${ }^{7}$ See, e.g., Chevron U.S.A. Inc. v. Natural Resources Defense Council, Inc., 467 U.S. 837, 844-45 (1984) (stating that an administrative agency may enforce a rule that is a "reasonable" interpretation of a statute even if a court would find that interpretation to be incorrect). 
are to define formalism as the false aspiration to doctrinal clarity and certainty, ${ }^{72}$ it seems difficult to deny that the increasing incidence of these rules reflects a new formality. One searches in vain for an example of a doctrinal rule created before 1945 in which the certainty and clarity of law itself played such an important and unabashed doctrinal role.

\section{A. The Meaning of "Clear Law"}

A foreign observer, aware of just a small amount of legal history, might become quite perplexed as she came upon these doctrines. She would note that, for much of the century, scholars and lawyers had challenged the idea that there was anything remotely like "clear law." Indeed, at the beginning of this century, the realists warned of the futility of "[c]ertainty-hunger and other superstitio[ns]." An yet, as we approach the year 2000, we find doctrine dripping off the pages of the federal reporters seeking "clearly established law," ${ }^{74}$ "unequivocally express[ed] intent," meaning." How could it be, in an age where some have come to believe that we are "all realists," openly for "clear law"?

A native speaker of constitutional law would point the puzzled observer to cases such as Harlow $v$. Fitzgerald, ${ }^{78}$ a constitutional tort action decided at the beginning of the 1980s. Harlow stands at the

${ }^{72}$ FRANK, supra note 36, at 3-13, 18 (decrying the "basic legal myth" of legal clarity as a "childish" and "unrealistic notion that law is, or can be made, entirely certain and definitely predictable").

${ }^{73}$ Id. at $87 ; \rightarrow$ Felix S. Cohen, Transcendental Nonsense and the Functional Approach, 35 ColUM. L. REV. 809, 812 (1935) (despairing that the law's language is "entirely useless" when it comes to actual prediction of legal phenomenon).

${ }^{74}$ See, e.g., Harlow v. Fitzgerald, 457 U.S. 800, 818 (1982) (limiting liability for constitutional torts to conduct that "violate[s] clearly established statutory or constitutional rights of which a reasonable person would have known").

${ }^{75}$ See, e.g., Atascadero State Hosp. v. Scanlon, 473 U.S. 234, 242 (1985) (holding that Congress waives Eleventh Amendment immunity only in cases where its intent to do so is "unequivocally express[ed]").

${ }^{76}$ See, e.g., Beecham v. United States, 511 U.S. 368, 374 (1994) (announcing that the Court's task is "to determine whether the language the legislators actually enacted has a plain, unambiguous meaning").

$\rightarrow$ iary Peller, The Metaphysics of American Law, 73 CAL. L. REV. 1151, 1152 (1985) ( $[$ [T]he received learning has been that legal analysis cannot be neutral and determinate, that general propositions of law cannot decide particular case $\rightarrow$ Joseph William Singer, Legal Realism Now, 76 CAL. L. REV. 467, 467 (1988) (reviewing KALMAN, supra note 6) ("We are all legal realists now.").

${ }^{78} 457$ U.S. 800 (1982). 
end of a long line of cases establishing that federal and state officials are immune from damage liability for constitutional violations if they can show that their conduct was undertaken in good faith. ${ }^{79}$ The Harlow Court, nervous about the increasing use of the tort remedy, focused on the subjectivity of the inquiry demanded by a rule based on "good faith," and decided to solve the problem by adopting a more stringent standard. Good faith, the Court announced, was not to be measured by the defendant's malice or intention, but by an objective standard based on "clearly established law." Henceforward, government officials would be "shielded from liability for civil damages insofar as their conduct [did] not violate clearly established statutory or constitutional rights."

Had the clear law rule stopped with Harlow, few might have taken note. But, within the next decade and a half, the clear law rhetoric would emerge far afield from its origins. From constitutional torts, the clear law language moved to the exclusionary rule. In Illinois $v$. Krull, the Court held that illegally obtained evidence would not be excluded at trial if the statute authorizing the seizure was not clearly unconstitutional, ${ }^{82}$ analogizing a constitutional ambiguity to the kind of good-faith search affirmed by the Court in United States $v$. Leon. ${ }^{83}$ From the exclusionary rule, the clear law rule moved to a new remedial field-habeas corpus. In the celebrated 1989 decision of Teague v. Lane, the Supreme Court barred habeas petitions based on "new rules," ${ }^{84}$ a phrase later defined by the Court, in Butler $v$. McKellar, ${ }^{85}$ as the set of rules upon which state judges could in good faith rely, again invoking Leon. After Butler, the price of a habeas

${ }^{79}$ See, e.g., Pierson v. Ray, 386 U.S. 547, 557 (1967) ("We hold that the defense of good faith and probable cause, which the Court of Appeals found available to the officers in the common-law action for false arrest and imprisonment, is also available to them in the action under $\S 1983$.").

${ }^{80}$ Harlow, 457 U.S. at 817-18.

${ }^{81}$ Id. at 818 .

${ }^{82} 480$ U.S. 340, 355-60 (1987) (applying the "good faith" exception created by United States v. Leon, 468 U.S. 897 (1984), and holding that, even if a statute authorizing warrantless administrative searches was unconstitutional, a police officer's good-faith reliance on that statute would bar application of the exclusionary rule); see also id. at 367 (O'Connor, J., dissenting) ("Under the decision today... courts are expected to determine at what point a reasonable officer should be held to know that a statute has, under evolving legal rules, become 'clearly' unconstitutional.").

${ }^{83} 468$ U.S. 897, 924 (1984) (creating a good-faith exception to the Fourth Amendment exclusionary rule)

${ }^{84} 489$ U.S. 288, 310 (1989).

${ }^{85} 494$ U.S. 407,414 (1990). 
petition was legal clarity: If state judges might reasonably disagree about the appropriate legal ruling, the rule sought was deemed "new," and the petition would be denied. ${ }^{86}$ And, just last year, Congress embraced its own version of the clear law principle, declaring in the Antiterrorism and Effective Death Penalty Act of 1996 that state judges' reasonable interpretations of "clearly established" constitutional law would not be subject to review in a habeas application. ${ }^{87}$

The rule of clear law seems to offer lawyers and judges a simple equation: Find unclarity in the law and you have solved the case-or at least a very large part of it. Judges may dismiss the constitutional tort claim, find the state official immune from suit, or deny a habeas petition as long as the court finds the law "unclear." In practice, however, this simple equation has proven extremely difficult to apply. The questions are obvious, yet perplexing. How clear must clear be? Is a rule clear if the principle it announces is clear, even though application to particular facts may be uncertain? What counts as law for the purposes of determining clear or unclear law? In the remedial context, ${ }^{88}$ these questions quickly multiply. Do conflicts in another circuit or between a circuit court and a district court count? What if the conflicting decisions are unpublished? ${ }^{89}$ Is "the case" its holding, its facts, or its announced rule? $?^{90}$ As the Supreme Court has

${ }^{86}$ In his Butler dissent, Justice Brennan summarized the connection between clear law and new rules. See id. at 417-18 (Brennan, J., dissenting) ("A legal ruling sought by a federal habeas petitioner is now deemed 'new' as long as the correctness of the rule . . . is 'susceptible to debate among reasonable minds.' Put another way, a state prisoner can secure habeas relief only by showing that the state court's rejection of the constitutional challenge was so clearly invalid under then-prevailing legal standards that the decision could not be defended by any reasonable jurist." (emphasis added) (footnote omitted)); see also Fallon \& Meltzer, supra note 64, at 1734-35, 1752 (equating, for some purposes, Teague's "new rule" doctrine with the "clearly established" law doctrine of the qualified immunity cases).

${ }^{87} 28$ U.S.C.A. $\$ 2254$ (d) (1) (West Supp. 1997).

${ }^{88}$ By this I refer to the clear law rules applicable in the context of constitutional torts, habeas, and some exclusionary rule claims. The courts' demand for a clear statement in Tenth Amendment and Eleventh Amendment cases focuses on the clarity of expression of legislatures, rather than courts, and thus invites questions about the collective meanings of other institutions.

${ }^{89}$ See, e.g., McCloud v. Testa, 97 F.3d 1536, 1555 n.28 (6th Cir. 1996) (arguing that unpublished decisions may be relied upon because they are likely to be uncontroversial and, therefore, create "no new precedent").

${ }^{90}$ Several scholars have noted these difficulties. See, e.g., Karen M. Blum, Qualified Immunity: A User's Manual, 26 IND. L. REV. 187, 199-205 (1993) (surveying courts' approaches to determining whether a right is "clearly established"); Fallon \& Meltzer, supra note 64, at 1751-53 (noting problems of specificity and authority in determining 
already recognized, if generality counts, all law may be clear; but, if specificity counts, then no law may be clear ${ }^{91}$ for these purposes.

In its remedial contexts, the clear law rule invites questions ranging from the mundanely difficult to the metaphysical. ${ }^{92}$ There are questions of geography (do decisions in other circuits make the law clear?), ${ }^{93}$ questions of timing (do decisions unnoticed until after the fact make the law clear?), ${ }^{94}$ and questions of scope (how closely must a precedent fit with the facts to find it controllingly clear?) ${ }^{95}$ At this point, our foreign observer-unwedded to these decisions or their place in the constitutional order-might begin to wonder why judges are trying to answer these rather heady questions. Do judges really need to develop a metatheory of law, legal change, and legal rules to decide tort cases? If the Court's purpose in creating these rules was to limit the number of frivolous constitutional claims or to slow the pace of legal change, ${ }^{96}$ there seem far easier ways to achieve those ends. The Court might have created procedural barriers (a

"'the state of the law'" required by clear law rules (quoting Harlow v. Fitzgerald, 457 U.S. 800, 818 n.32 (1982))); Meyer, supra note 64, at 1505-11 (discussing the "level of generality" and the "multiple sovereigns" problems).

${ }^{91}$ See Anderson v. Creighton, 483 U.S. 635, 639 (1987) ("The operation of this [objective legal reasonableness] standard ... depends substantially upon the level of generality at which the relevant 'legal rule' is to be identified."); see also Meyer, supra note 64, at 1507-10 (discussing the dilemma surrounding "levels of generality" as addressed by the Sixth and Ninth Circuits in two recent conflicting holdings).

${ }^{92}$ On the difficulty of the jurisprudential questions raised, see generally Fallon \& Meltzer, supra note 64, at 1758 (noting that decisions about the clarity of legal change "raise profound issues of jurisprudential theory"), a $\rightarrow$ Linda Meyer, "Nothing We Say Matters": Teague and New Rules, 61 U. CHI. L. REV. 423, 459-76 (1994) (discussing how Teague's new rule doctrine relies on theories of precedent, borrowed from the positive law and common law).

${ }^{93}$ See, e.g., Ohio Civil Serv. Employees Ass'n v. Seiter, 858 F.2d 1171, 1175-77 (6th Cir. 1988) (concluding that decisions of other circuits cannot establish "clear law" except in the extraordinary case).

${ }_{94}^{94}$ See, e.g., Martin v. Heideman, 106 F.3d 1308, 1313 (6th Cir. 1997) (acknowledging that the court was applying a 1993 precedent to show that the law was clearly established in 1991, when the incident happened); see also Elder v. Holloway, 510 U.S. 510,512-16 (1994) (rejecting the Ninth Circuit's position that precedent unnoticed by the district court was too late to be relevant to the "clear law" question).

${ }^{95}$ See, e.g., Anderson, 483 U.S. at 639 (acknowledging that most legal rights are "clearly established" at some level of generality and that plaintiffs could defeat the rule of qualified immunity simply by alleging violation of an abstract legal right); Martin, 106 F.3d at 1312-13 (reversing the district court's determination that the law was unclear based on a series of opinions from various district and appellate courts by redescribing the right at a more general level-as the right to be free from excessive force rather than the right to be free from "excessively forceful handcuffing").

${ }^{96}$ See Fallon \& Meltzer, supra note 64, at 1793 n.327 (summarizing the frivolous claims argument); $i d$. at 1798 n.355 (summarizing the law-freezing argument). 
particularly stringent pleading rule, for example), or might simply have decided the constitutional questions. After all, the Court premised its embrace of clear law on the assumption that many of these claims were "insubstantial." ${ }^{97}$ If there are easier ways, then what does it mean that courts seem to be taking the harder path by trying to define legal clarity? And trying so hard in so very many places?

\section{B. Justice as Clarity}

Our foreign observer might suggest, at this point, that the rule of clear law is peculiarly self-conscious: Doctrine itself has become an object of judicial study. Rather than asking the question, "What constitutional norms should decide this issue?", courts are required to ask, "How clearly did we describe the law in our past decisions?". In essence, this forces the judge's gaze on the behavior of legal institutions themselves; the parties to the dispute, as well as the factual and normative contest, recede in importance compared to the state of the doctrine. Perhaps more importantly, the rule reduces judicial behavior to the clarity of textual expression: The relevant question is, "How clearly did we say it?", not "What are the consequences of what we have said?". In this world, precedent is measured by whether it equivocates rather than whether it binds. Law becomes textual artifact rather than command.

Could this self-conscious struggle have come from nowhere, descending without warning or design? The influences are no doubt various. ${ }^{98}$ But, at the same time, it seems difficult to believe that such

${ }^{97}$ Harlow v. Fitzgerald, 457 U.S. 800, 813-14 (1982). In damage actions, the argument for a "clear law" standard has often been based on the notion that a "subjective" rule (based on the official's state of mind) would allow many nonmeritorious cases to proceed through discovery and trial because, on summary judgment, the plaintiff's complaint would raise an issue of fact based solely on the official's state of mind. See id. at 815-16. It does not follow, however, that nonmeritorious claims must proceed simply because of the mental state alleged. For example, a claim that an official maliciously searched the plaintiff's garbage can easily be dismissed without regard to the official's state of mind, because there is no constitutional limitation on such searches. Only in a case where the mental state was essential to the constitutional claim would the case proceed. Then, however, we face the question of how the Court knows that these cases are, indeed, nonmeritorious $e x$ ante, before there has been discovery or trial.

${ }^{98}$ In what follows, for example, I emphasize the realist critique of common law decisionmaking, although one can also see quite easily the influence of ideas associated with positivism and legal process. I make no claim of having found "the" scholarly source of modern constitutional doctrine, but only that doctrinal vocabularies reflect prevailing ideals of the judicial institution. But, even so, it is worth 
a rule could have been created in an age confident of the common ideal of judging. No nineteenth-century court would have reached out to embrace the idea that law was uncertain; indeed, no nineteenth-century court would have conceived of its job in a way that would have permitted it to embrace such a rule. The common law model assumes that law transcends text, ${ }^{99}$ that it is seamless and is in this sense profoundly "unwritten." ${ }^{100}$ In fact, the clear law rule assumes quite the opposite-that law is made rather than found, that it is textual rather than transcendent, that it is uncertain rather than seamless. And, in proceeding on these assumptions, it betrays a world in which the common law ideal of judging has come to be viewed with suspicion.

The clear law rule takes a standard critique of the common law ideal of judging and transforms that critique into doctrine itself. Consider the charge, hailing back to Holmes and popularized by the realist movement, that law is merely the prediction of the "behavior" of judges. ${ }^{101}$ There is no clearer (no pun intended) evidence of this

noting that both positivism and legal process are not unrelated to realism and, indeed, may be seen as reactions to, or embodiments of, some tenets of realism. See Neil Duxbury, Faith in Reason: The Process Tradition in American Jurisprudence, 15 CARDOzO L. REV. 601, 623 (1993) (discussing Lon Fuller's argument that realism is simply an example of positivisn $\rightarrow$ Edward L. Rubin, The New Legal Process, The Synthesis of Discourse, and the Microanalysis of Institutions, 109 HARV. L. REV. 1393, 1396 (1996) (noting that the legal process model was an attempt to accommodate and respond to the realist critique). From such a perspective, it would not be surprising to see traces of legal process or positivism in the constitutional doctrine of the post-war era.

${ }_{99} \rightarrow$ John Dickinson, The Law Behind Law, 29 CoLuM. L. REV. 113, 117 (1929) ("The theory of the common law ... insists that in cases of first impression the court must not be regarded as exercising an active legislative choice among a number of possible ... rules .... On the contrary, a body of rules is supposed to be already in existence which stands ready to decide all possible cases.").

100 See Melvin Aron Eisenberg, The Nature of the Common LaW 156 (1988) ("Text-based theories instruct a court to start with doctrinal propositions promulgated in past texts by officials [and to] ... work backward down a chain of authorization to determine whether the propositions are valid, and if they are, apply them to cases. This is not how courts determine the content of the common law."); GERALD J. Postema, Bentham AND the COMmON LAW TRAdition 14-29 (1986) (discussing common law theory as law based on custom which "defined its conception of law in sharp contrast with written or enacted law, 'lex scripta"').

${ }^{101}$ See Walter Wheeler CoOK, The Logical and Legal BaSes of the Conflict OF LAWS 29 (1942) ("As practicing lawyers we are interested in knowing how certain officials of society-judges, legislators, and others-have behaved in the past, in order that we may make a prediction of their probable behavior in the future." (emphasis added)); FRANK, supra note 36, at 47 (stating that law is "in fact prophecies or predictions of judicial action" and that "[i]t is from this point of view that the practice of law has been aptly termed an act of prediction" (footnote omitted $\rightarrow$ Underhill Moore \& Theodore S. Hope, Jr., An Institutional Approach to the Law of Commercial Banking, 38 
kind of behaviorism than the clear law rule. When judges apply the rule, they do not treat prior opinions as commands but instead as judges' "behavior"-what judges have said in the past. In effect, judges acknowledge the power of prior precedent, but alienate themselves from it, distancing themselves from their own authority. ${ }^{102}$ Indeed, the clear law rule is the very embodiment of the idea that law is a matter of prediction as applied to doctrine itself. As the Supreme Court put it in Teague $v$. Lane, a law that fails to predict (to clearly "dictate" an outcome) may not be governing constitutional law at all. ${ }^{103}$

Perhaps more importantly, consider how the clear law rule has absorbed the classic critique that courts "make" law rather than "find" it in some transcendent universe. ${ }^{104}$ There is no more obvious case of courts treating their own doctrine as "made" than the clear law rule. Clear law rules ask courts to find the "plain meaning" of their prior precedent. Courts put themselves in the position typically reserved for legislatures, asking statutory interpretation questions of themselves. Remember all of the difficulties that the clear law rule posed: about the interpretation of prior precedents, about whether the courts were a single collective entity, and about what level of specificity could be used to describe the claim. ${ }^{105}$ Now compare these difficulties-of textual ambiguity, collective meaning, and levels of generality-to our debates about statutory interpretation. The only difference here is that courts must ask these questions of cases and judicial history,

YALE L.J. 703, 703 (1929) ("The central problem of the lawyer is the prediction of judicial and administrative decisions of government officers." (emphasis added)). These can be traced back, of course, to the famous Holmesian statement that " $[t]$ he prophecies of what the courts will do in fact, and nothing more pretentious, are what I mean by the lai $\rightarrow$ O.W. Holmes, The Path of the Law, 10 HARV. L. REV. 457, 461 (1897).

${ }^{102}$ When applying the clear law rule, courts defer to statements of law found in other opinions to determine the level of clarity with which a particular proposition is stated. This leads to a kind of legal self-alienation, which Linda Meyer aptly has described as "nothing we say matters." Meyer, supra note 92.

${ }^{103} 489$ U.S. 288, 301 (1989) (plurality opinion) (“[A] case announces a new rule if the result was not dictated by precedent existing at the time the defendant's conviction became final.").

${ }^{104}$ See FRANK, supra note 36, at 128 ("[W] henever a judge decides a case he is making law." (emphasis omitted)); id. at 36-37 (explaining that the denial of "judicial law-making" is judicial "self-deception"); id. at 121 ("The power [of judges] to individualize and to legislate judicially is of the very essence of their function."); LLEWELLYN, supra note 27 , at 66 ("[T] he way to deal with a [legal] situation is to look at the situation and its needs, and if no appropriate concept is available, then to make one.").

${ }^{105}$ See supra text accompanying notes 89-95. 
rather than statutes and legislative history. ${ }^{106}$ The clear law rules demand not, as Judge Calabresi once put it, a common law for an "age of statutes," 107 but rules of statutory interpretation for virtual legislation.

My point is not that doctrine has in fact adopted common law critiques or become more realistic. ${ }^{108}$ It is that the clear law rule is not only a rule, it is a job description. When courts create a doctrine that requires them to find the "plain meaning" of their prior texts, they describe themselves in ways that betray a particular self-image, an image that departs significantly from the common law ideal. Treating opinions as what they say, rather than what they command, creating a rule that requires courts openly to acknowledge, and find, "unclear" rather than transparent law, and making doctrine depend upon shifting, rather than permanent, linguistic traditions are all signs of a court that views its job in terms that no nineteenth-century judge could ever understand.

If the clear law rule assumes a judicial role far different from the common law ideal, it also suggests a sensitivity to judicial criticism that is peculiarly modern. Indeed, in a strange sense, the rule of clear law seems almost the embodiment of Jerome Frank's injunction that the law analyze itself, that it become "self-conscious" of its own status in the legal world. ${ }^{109}$ Once upon a time, the notions that law was uncertain, nothing more than a prediction of the behavior of lawyers,

${ }^{106}$ Clear law cases raise, for example, questions about the meaning of a prior precedent when judges disagree. See, e.g., Ohio Civil Serv. Employees Ass'n v. Seiter, 858 F.2d 1171, 1175-76 (6th Cir. 1988) (considering questions about the meaning of judicial intent when there are conflicting out-of-circuit opinions). Such cases even raise questions about whether certain kinds of "judicial history" (for example, unpublished opinions or post-hoc decisions) should count. See, e.g., Martin v. Heideman, 106 F.3d 1308, 1312-13 (6th Cir. 1997) (considering post-hoc judicial history-using a case decided in 1993 to determine clear law in 1991); McCloud v. Testa, 97 F.3d 1536, 1555 \& n.28 (6th Cir. 1996) (considering the question of whether judicial history that amounts to "unpublished" material should be considered in determining clear law).

${ }^{107}$ Guido CALABresi, A COMmON LAW FOR THE AgE of STATUTES (1982).

108 See infra text accompanying notes 111-12.

${ }^{109}$ Of course, Frank intended that this self-analysis would lead judges to reveal their social and political motivations. See FrANK, supra note 36, at 114-15 ("What we may hope some day to get from our judges are detailed autobiographies... or opinions annotated... with elaborate explorations of the background factors in [their] personal experience which swayed [them] in reaching [their] conclusions."). The clear law rule, by contrast, applies this autobiographical injunction to the law itself, giving us doctrinal, rather than judicial, autobiography. This, in turn, yields an odd reversal: Rather than a truly realist exposition of a judge's motivations, doctrine that is self-conscious provides an autobiography of itself. 
and a matter of "judicial legislation," were considered trenchant criticisms of judicial aspirations. Today, doctrines like the clear law rule reflect some version of these criticisms.

The most important point to see here, however, is that all of this effort to absorb criticism turns out, in the end, to preserve a space where law stands safe from critique. Indeed, one of the most fascinating aspects of the clear law rule is how it both reflects institutional doubt at the same time that it cabins it. A doctrine that truly sought to absorb the indeterminacy critique would be a blank canvas. By contrast, a doctrine that looks for "clear law" leaves room for the possibility of law that is truly clear and may be found. The beauty of doctrinalizing the institutional critique is that it gives hard edges: outside the edges the law is unclear, but, inside, it is as clear as it can be. Using traditional technique-the creation of bounded categories-doctrine has managed both to bow to judicial critics and, at the same time, to sustain faith in judicial legitimacy. It has simply incorporated this battle into the lines it asks courts to draw between "clear" and "unclear" law.

To see that there is a price to be paid for incorporating this battle within doctrine, however, it is important to understand how litigants may find themselves bearing the burden of the fight. The stated aim of many clear law rules is to give notice to government officials that their actions are constitutionally impermissible. ${ }^{110}$ But the doctrine has not been applied this way; when a court looks to determine whether the law is unclear, it does not ask whether the law would be unclear to a layman. Instead, it applies standards of certainty that only a lawyer, indeed, only a judge, could know or apply. When the constitutional tort suit against the building manager is dismissed because the law is unclear, the standard is not the unclarity to the building manager, but the unclarity to judges. ${ }^{11}$ What average

${ }^{110}$ One of the principal arguments for such rules is that they refuse to apply impossible standards of legal acumen to ordinary government officials. See Fallon \& Meltzer, supra note 64, at 1791 (noting the unfairness of imposing liability on government officials who have "reasonably relied on authoritative pronouncements of constitutional law"); Meyer, supra note 64, at 1503 (arguing that the focus in qualified immunity cases is "fair notice to governmental officials"). The irony, of course, is that, as applied, the rules measure uncertainty by the uncertainty of lawyers, not laymen.

${ }^{111}$ Lest this appear an unlikely example, I litigated just such a case in the Fifth Circuit on behalf of the Justice Department, representing a low-level federal building manager who was sued for violating the plaintiff's First Amendment rights. (The plaintiff sought to pass out a mock FBI "Wanted" poster of Ronald Reagan that the manager believed deceptively resembled a real FBI poster.) The case was insubstantial because the plaintiff suffered no damage; the leaflets were distributed. Litigating the 
government employee do you know who understands that he may ignore a district court in the city next door because, after all, it is in a different circuit? ${ }^{112}$ Or that he could be bound by an opinion that was officially "unpublished" or decided after the events in question? Even in habeas cases, where the government officials involved are state judges, the inquiry is not about the "lived" uncertainty of the judges who decided the original appeal, but an abstract, ungrounded question of whether precedent would have "dictated" a different outcome. $^{113}$

In a sense, the rule of clear law measures the justice of real-life claims by law's own sense of uncertainty. Herein lies the danger of a modernist, inward-looking rhetoric. It is not that the people are "left out" of the Court's opinions or that the resulting style is too formulaic. It is that an institution that asks doctrine to answer difficult questions about law and legal clarity may indulge its own institutional insecurities at the expense of the litigants. In classical architecture, the Ionic column that is perfectly rendered may inspire our contemplation and admiration, but, if it cannot bear weight, it will leave a building in collapse. So, too, a rule which focuses on courts' own institutional self-image may leave litigants with little to stand upon. There are real institutional choices to be made in these cases, but the rule of clear law does not help us make those choices. ${ }^{114}$ The doctrine keeps us focused on the "clarity" of the court's own texts. And, in so doing, it asks litigants to bear the costs of the court's own self-consciousness-costs that must be measured not only in the

clear law issues, however, raised some difficult questions about the "clarity" of the law and how specifically one should describe the "right" at issue (was it the right to free speech, the right to pass out leaflets in a public building, or, as the manager claimed, the right to pass out leaflets that were misleadingly like FBI Wanted Posters?). Perhaps this explains why the appellate court simply reversed without opinion. See Foster v. Bowen, 866 F.2d 1419 (1989).

${ }^{112}$ Although some courts seem to have recognized this difficulty, they have resisted its implications for all cases. See, e.g., Ohio Civil Serv. Employees Ass'n v. Seiter, 858 F.2d 1171, 1175-76 (6th Cir. 1988) (expressing doubt that out-of-circuit decisions can make law "clear," without acknowledging that the defendants were as unlikely to be aware of decisions within the circuit as without).

${ }^{113}$ See, e.g., Butler v. McKellar, 494 U.S. 407, 409 (1990) ("We have held, however, that a new decision generally is not applicable in cases on collateral review unless the decision was dictated by precedent existing at the time the petitioner's conviction became final.").

${ }^{114}$ Indeed, it tends to obscure the choices by focusing on the court's image without considering the court's role vis-à-vis other institutions. See KOMESAR, supra note 21 , at $6,134-50$ (describing how comparative institutional analysis would ask these questions). 
time spent in answering questions about "what law counts" and "how clear is clear," but also in a legal system that purports to measure the justice of a claim against a government building manager by legal intricacies only judges and lawyers could know.

\section{INTERESTS AND EXPECTATIONS}

If the clear law rule seems outside the core of standard constitutional law concepts, let me expand the scope of the inquiry to more familiar territory. One cannot be a native speaker of modern constitutional law without being well-versed in a rather complex rhetoric of expectation and interest. ${ }^{115}$ Indeed, the architecture of much standard constitutional law depends upon the notion that there are constitutional "interests" that can be identified and classified in various ways (as fundamental or compelling, as social or economic, or in other ways), and that these classifications tell us which "perspective" to take on the claim (whether to strictly scrutinize or defer). ${ }^{116}$ The "rule of perspective" is my shorthand for a tendency to craft legal doctrine in a way that does not purport to direct conduct per se, but instead points the judging party to a certain imaginative position vis-à-vis the case, toward or against one party, for or against a particular argument.

Interests and expectations are as ubiquitous in modern constitutional law as are the rules of perspective that enforce them. ${ }^{117}$ Indeed, rules of perspective have become a popular way of creating new constitutional doctrine. Thus, in criminal procedure, when asked to decide how to determine what qualifies as a "search," or

${ }^{115}$ Casebooks indoctrinate students quite openly in the language of metaconstitutional law. See, e.g., GeOfFrey R. StONE ET AL., CONSTITUTIONAL LAW 561 (1996) ("One therefore cannot understand the equal protection clause without first understanding the general methodology courts use to resolve equal protection disputes.... In recent years, the Court's approach has involved creation of various 'tiers' of review. ... [C] lassifications not drawn on a 'suspect basis' are subject to 'low-level' or 'rational basis' review ....").

${ }^{116}$ See id. at 842; JoHn E. NOWAK \& RONALD D. ROTUNDA, CONSTITUTIONAL LAW $\S 14.3$, at $600-06$ (5th ed. 1995).

${ }^{117}$ These concepts extend far beyond the area of individual rights with which they are typically associated. See, e.g., Kassel v. Consolidated Freightways Corp., 450 U.S. $662,670-71$ (1981) (requiring in a dormant commerce clause case a perspective that is "sensitive" to "the weight and nature of the state regulatory concern in light of the extent of the burden imposed on the course of interstate commerce"). 
whether a person is "in custody" for purposes of applying Miranda, ${ }^{118}$ or the proper standard for a Terry stop, ${ }^{119}$ the Court reaches out to a rule of perspective; the Court tells the applier of the law that the search, custody, or stop depends upon the interests and perspective of a reasonable person in the situation. ${ }^{120}$

Of course, rules of perspective can be traced to concepts as old as the republic, as can the concept of "interest" in constitutional law. ${ }^{121}$ Still, it is difficult to believe that we could simply replace the modern rhetoric of interest and perspective with the rhetoric of another time or place. Once upon a time, courts spoke of litigants' claims and arguments, not their interests or expectations, and they applied a rule of constitutional arbitrariness rather than a complex metataxonomy of constitutional scrutinies. ${ }^{122}$ Lest we doubt the change, all we need to do is consider how older common law concepts such as "the police power" or "vested rights" might have looked had they emerged in an age of "interest and expectation." The police power might have been "a compelling police interest." "Vested rights" might have been those rights in which the complainant had an "expectation of security." To enunciate these rules is to embrace anachronism; it is to impose the ring of modern doctrine upon an older, largely forgotten, discourse.

It is possible, of course, that nothing much hangs on how these rules are expressed-that it does not matter whether we use the term "interest" or "expectation" or whether the rule is framed in terms of a perspective. On the other hand, there are reasons to question why the shift seems so natural today. Many constitutional rules might have been stated in different ways. Rather than saying, for example, that privacy or security depended upon the "expectation" of the parties, the Court might simply have enumerated impermissible

${ }^{118}$ Miranda v. Arizona, 384 U.S. 436 (1966); see, e.g., Berkemer v. McCarty, 468 U.S. 420,442 (1984) ("[T] he only relevant inquiry [in custody cases] is how a reasonable man in the suspect's position would have understood his situation.").

119 Terry v. Ohio, 392 U.S. 1 (1968); see, e.g., Florida v. Bostick, 501 U.S. 429, 436 (1991) (defining "free to leave" as "whether a reasonable person would feel free to decline the officers' requests or otherwise terminate the encounter").

${ }^{120}$ See, e.g., Katz v. United States, 389 U.S. 347, 361 (1967) (Harlan, J., concurring) (defining a search for Fourth Amendment purposes in terms of a reasonable person's expectation of privacy).

${ }^{121}$ The Federalist Papers, for example, cannot be understood without a healthy appreciation of the meaning of the term "interest." See Victoria Nourse, Toward a "Due Foundation" for the Separation of Powers: The Federalist Papers as Political Narrative, 74 TEX. L. REV. 447, 478-81 (1996).

${ }^{122}$ See infra note 138. 
government intrusions. ${ }^{123}$ Similarly, rather than developing a hierarchy of scrutinies, the Court might have stated that some reasons, such as race, are almost never a reason to disadvantage persons. That these rules might have been stated this way, however, does not explain why courts have clung to a different rhetoric.

\section{A. Perspective, Considered}

A foreign observer looking for help understanding the role of interest, expectation, and perspective in one of its more straightforward appearances might do well to start with Katz $v$. United States, ${ }^{124}$ the quintessential modern criminal procedure decision. In Katz, the Supreme Court held that the Fourth Amendment barred warrantless government wiretaps to overhear conversations in a public telephone booth. ${ }^{125}$ In so holding, the Court refused to limit the Fourth Amendment's protection to governmental trespass, ${ }^{126}$ instead concluding that a search depended upon an individual's "right to privacy." ${ }^{27}$ The doctrinal rule, taken from Justice Harlan's concurrence, was that a search was to be judged by the defendant's "expectation of privacy."

Although it is difficult to see today, the Court need not have created a rule of perspective to decide Katz. Existing doctrine could not yield the result the Court chose: Rules of trespass left Mr. Katz's case uncovered, and deciding that a public telephone booth was a "constitutionally protected area" ${ }^{29}$ seemed constitutional hyperbole. On the other hand, there were alternatives. For example, the Court

${ }^{123}$ See infra notes 130-32 and accompanying text (discussing different ways in which the Fourth Amendment search rule might have been formulated).

124389 U.S. 347 (1967).

${ }^{125}$ See id. at 353 ("The Government's activities in electronically listening to and recording the petitioner's words violated the privacy upon which he justifiably relied while using the telephone booth ....").

${ }^{126}$ See id. ("We conclude that...the 'trespass' doctrine... can no longer be regarded as controlling.").

${ }^{127}$ See id. at 350-51 (contrasting the individual's right to privacy under the Fourth Amendment with a person's more general right to privacy governed by the states); see also id. at 353 ("The Government's activities . . . violated the privacy upon which he justifiably relied ....").

${ }^{128}$ See id. at 361 (Harlan, J., concurring) ("My understanding of the rule ... is that there is a twofold requirement, first that a person have exhibited an actual (subjective) expectation of privacy and, second, that the expectation be one that society is prepared to recognize as 'reasonable.' ).

${ }^{129}$ See id. at 349-50 (noting that petitioner's questions were directed to whether a phone booth was a "constitutionally protected area"). 
might have ruled that the government must justify its use of technology to obtain information that the human senses cannot. ${ }^{130}$ Or, the Court might have expressed its ruling in terms of propertythat the government may not, without justification or consent, appropriate conversations of private citizens for public use. ${ }^{131}$ Or it might have expressed the rule in terms of due process-that the government may not, without justification, profit from taking action which, if taken by private parties, would amount to a violation of law. ${ }^{132}$

Each of these approaches differs rather distinctly from the rule adopted in Katz precisely because that rule is one of perspective. Rather than asserting substantive authority, such rules assert methodological authority: Courts are asked to decide by placing themselves in a particular position vis-à-vis the parties and their claims. Just as a rational basis rule tells judges to take a particular intellectual stance with respect to the government's justification, the Katz rule tells judges to take a particular intellectual stance with respect to defendants' expectations. This imaginative exercise, by which the court is asked to identify or distance itself from the litigants or their claims, is then tempered by a rule against self-interest: The defendant's perspective or the state's interest will be honored only if found "reasonable" or "legitimate."

The great and well-known difficulty of Katz's rule is its tendency to dissolve into circularity. Shortly after Katz was decided, Professor Anthony Amsterdam demonstrated this quite easily. He simply asked us to consider the possibility that "the government could diminish each person's subjective expectation of privacy merely by announcing half-hourly on television that . . . we were all forthwith being placed under comprehensive electronic surveillance." ${ }^{133}$ Once everyone expects to be spied upon, individuals not only lose their "subjective" expectation of privacy, but risk the loss of their objective expectation

${ }^{130}$ See, e.g., United States v. Karo, 468 U.S. 705, 714 (1984) (holding that the government must justify its use of tracking beepers when these electronic devices allow agents to monitor persons or property withdrawn from public view).

${ }^{131}$ See WHITE, supra note 37, at 143 (suggesting possible property-type arguments in the wiretapping context).

${ }^{132}$ This argument is derived from the famous principle enunciated by Justice Brandeis in Olmstead that "[i]f the Government becomes a lawbreaker, it breeds contempt for law; it invites every man to become a law unto himself." Olmstead v. United States, 277 U.S. 438, 485 (1928) (Brandeis, J., dissenting).

139 Anthony G. Amsterdam, Perspectives on the Fourth Amendment, 58 MINN. L. REV. 349,384 (1974). 
as well: If everyone anticipates government surveillance, a contrary expectation may well seem unreasonable. As Amsterdam's hypothetical illustrates, if we change the world in ways that seem grossly unfair or dangerous, rules of perspective risk deference to that unfairness or dangerousness. ${ }^{134}$ And they do so precisely because they purport to be rules of perspective-because they ask courts to reach a legal conclusion based on what are assumed to be the preexisting interests and expectations of the parties.

The most fascinating aspect of this story is not how it ended, but that it has been repeated so often, despite persistent doubts that this doctrinal method can really deliver the "realism" or the "justice" that it promises. The "search" cases, for example, end up being decided based on whether the court declares the parties' expectations to be "reasonable," yielding results that often depart from what people say are their "real" expectations of privacy. ${ }^{135}$ A similar phenomenon can be seen in other areas of constitutional law. Indeed, it is now conventional wisdom that the most important question in many constitutional cases is how the court should characterize a perspective or interest or right (as compelling or legitimate or fundamental) ${ }^{136}$ a process that may or may not yield results consistent with public expectation. Not surprisingly, there is no ready correlation between rules of perspective and sound constitutional results. Korematsu's twentieth-century reference to the "most rigid scrutiny" ${ }^{\text {"137 }}$ has not saved it from constitutional disgrace any more than Yick Wo's reliance

${ }^{134}$ See Nourse, supra note 19 , at 1374-80 (discussing an analogous process in the context of criminal law).

$\dddot{\rightarrow}$ Christopher Slobogin \& Joseph E. Schumacher, Reasonable Expectations of Privacy and Autonomy in Fourth Amendment Cases: An Empirical Look at "Understandings Recognized and Permitted by Society", 42 DUKE L.J. 727, 737-42 (1993) (reporting results of an empirical study showing that the "expectations" rule in the Fourth Amendment context has yielded results distinctly different from people's "actual" expectations of privacy).

${ }^{136} \rightarrow$ Gerald Gunther, The Supreme Court, 1971 Term-Foreword: In Search of Evolving Doctrine on a Changing Court: A Model for a Newer Equal Protection, 86 HARV. L. REV. 1, 8 (1972) (noting that the choice of a level of scrutiny often determines the outcome of a particular ca: $\rightarrow$ Laurence H. Tribe \& Michael C. Dorf, Levels of Generality in the Definition of Rights, 57 U. CHI. L. REV. 1057, 1057, 1065 (1990) (noting that "whether to designate a right as fundamental poses a central substantive question in modern constitutional law," a question that often depends upon "competing characterizations of the level of generality" at which to describe the right in question).

${ }^{137}$ Korematsu v. United States, 323 U.S. 214, 216 (1944). 
on the ancient constitutional language of "arbitrariness" has hindered constitutional praise. ${ }^{138}$

\section{B. Justice as Culture}

Given the difficulties, why have courts chosen to embrace constitutional perspectivism in such a vast array of forms and cases? If we imagine that doctrinal formulations reflect courts' image of themselves, the origins of these rules may become clearer. Think about it for a minute: redescribing the "police power" as a "police interest" jars the native speaker of constitutional law, not only because of linguistic habit, but also because it brings together two very different ideas of law and courts. A police "interest" suggests that the court's job is to describe and defer to what exists "out there" in the real world; a police "power" suggests quite a different judicial rolethat the court does not defer to, but commands, legal relationships, and that it does so without regard to real world analogues. Subtly perhaps, but nevertheless clearly, the rhetoric portrays an institutional image-one which pits a common law ideal of courts against a seemingly more "realistic" ideal, one in which courts aspire to arbitrate social interests rather than to master the established doctrinal order.

This shifting ideal came, of course, from somewhere, and rules of perspective betray those influences. ${ }^{139}$ It hardly seems a coincidence, for example, that judges of the post-war period would embrace doctrinal terms reflecting social "interests." Would it have been possible to graduate from law school in the 1940s and 1950s, as the judges of the 1970s and 1980s did, without learning that the Supreme Court had precipitated a constitutional crisis when it preferred concepts of property and contract to "social interest" and "situation-

${ }^{138}$ Yick Wo v. Hopkins, 118 U.S. 356, 366, 367 (1886) (recounting the common nineteenth-century understanding that the Fourteenth Amendment barred the "arbitrary deprivation of life or liberty," and that the ordinance in question granted authority to the government that was "purely arbitrary"); see GILLMAN, supra note 56, at 72 (arguing that the Court in Yick Wo concluded that the ordinances at issue were arbitrary because they were "based simply on favoritism or spite, and not on any 'good reason" related to the general welfare).

${ }^{139}$ The image of judging as arbitration can be traced to the realist critique of the common law ideal. See, e.g., FRANK, supra note 36, at 157 ("The judge, at his best, is an arbitrator.... [T] he arbitral function is the central fact in the administration of justice."). 
sense"? ${ }^{140}$ Indeed, Dean Pound's sociological jurisprudence insisted that a vocabulary of social interests should replace common law concepts. ${ }^{141}$ And, although the legal realists rejected Pound, ${ }^{142}$ they, too, decried the old, failed formalism because it did not reflect "the realities of ever-changing social, industrial and political conditions." 143

With this history in mind, it is easier to see how rules of perspective reflect modern indictments of the common law ideal. What better way to make the law reflect social interests than to create doctrinal rules that depend quite openly on those interests? If the common law model focuses too heavily on the "ought" rather than the "is," "144 what better way to correct that error than by acknowledging that law is a matter of "perspective"? ${ }^{145}$ If the common law model failed to recognize that facts were more reliable than values, ${ }^{146}$ then

${ }^{140}$ Llewellyn specifically recommended that the "forecasting" and "prediction" of the "ordinary lawyer" was better achieved when "situation-sense" helped to "reshap[e] ... the doctrinal materials used." LLEWELLYN, supra note 27, at 199. Llewellyn meant many things by "situation-sense," of course, variously defining it in his later years as "the facts of the situation taken as a type," id. at 122, and a "fact-pattern" that "carrie[d] within itself its appropriate, natural rules, its right law." Id. (quoting Levin Goldschmidt).

${ }^{141}$ See, $1 \rightarrow$ Roscoe Pound, The End of Law as Developed in Legal Rules and Doctrines, 27 HARV. L. REV. 195, 225-34 (1914) (noting that "a movement is taking place palpably in the law of all countries today," emphasizing "social interes $\rightarrow$ Roscoe Pound, $A$ Survey of Social Interests, 57 HARV. L. REV. 1, 13 (1943) (originally published as A Theory of Social Interests, 15 PAPERS \& PROC. AM. SOC. SOC'Y 16 (1921)) ("In general, but not always, it is expedient to put claims or demands in their most generalized form, i.e., as social interests, in order to compare them.").

${ }^{142}$ Llewellyn's famous article on realism seems both to praise Pound's "balancing of interests," and, at the same time, to ask "how" one "tell[s] an interest when you see one." Llewellyn, supra note 36 , at 435 \& n.3.

${ }^{143}$ FRANK, supra note 36, at 7; see Cohen, supra note 73, at 812 (criticizing opinionwriting "apt to forget the social forces which mold the law and the social ideals by which the law is to be judged"); Horwitz, supra note 1, at 209 ("[The r] ealists agreed that law needed to be brought back in touch with life, that legal categories needed to reflect better or express a more complex social reality.").

${ }^{144}$ HoRwITZ, supra note 6 , at 212 (noting the charge, made by Fuller, that the realists sought to make the "Ought acquiesce in the Is").

145 Normative "relativism" is a feature of some realist writing. See AMERICAN LEGAL REALISM, supra note 6, at 169 ("One aspect of the Realists' outlook... was their ambivalence concerning the origins and status of moral propositions. A few members ... forthrightly adopted the stance of ethical relativism ....").

${ }^{146}$ Early realist critiques were strongly influenced by the idea that facts and experience are more reliable than rules or values. See, e.g., AMERICAN LEGAL REALISM, supra note 6, at 166 (noting that many realists insisted "that, to be meaningful and useful, [legal] generalizations must be empirically based (derived from verifiable data) and narrow (incorporating only a small collection of manifestly similar situations or propositions).”). 
what better way to cure this blindness than to focus courts on the job of describing real-life interests and expectations?

A court that reaches out to embrace a doctrinal rule based on social expectations and interests announces not only a job description, but also a preferred legal method. A common law model proceeds by emphasis on backward-looking analogical reasoning. ${ }^{147}$ By contrast, a rule of perspective is decidedly forward-looking: It tells the reader how to attend to the decisionmaking process, to imaginatively identify with one of the parties or the arguments at issue. Didactic rather than authoritative, rules of perspective try to teach us how to intellectually attack the problem rather than to prescribe solutions. Summoning such directions appears to point the way to predict, enhancing the court's sense of its candor about decisionmaking. ${ }^{148}$ Soon, the facts and holdings so important to the common law method recede in importance relative to questions about the proper level of scrutiny, the nature of the interest, or the character of the expectation. ${ }^{149}$ Backward-looking analogy is placed in the service of the new emphasis on methodology. ${ }^{150}$

This account of critique being absorbed by doctrine tells only half the story, however. As we have seen before, incorporating such critiques within doctrine has a way of sustaining older ideals. The other half of this story, then, is how rules of interest and expectation end up cabining the critique. If law were only culture or perspective, of course, we would need no law at all. But bending perspective to doctrinal rule puts hard edges around the critique, leaving substantial room for the old-fashioned exercise of judicial authority and command. Just as the rule of unclear law leaves room for clear law, rules of interest and expectation leave room for something more than

${ }^{147}$ The common law focus on analogical reasoning was a favorite target of realist attack. See HORWITZ, supra note 6, at 205 (noting that realism had "drawn into question" the "process of analogy itself ... as fundamentally political," and that, for many realists, analogy was, in effect, "judicial legislation").

${ }_{148}$ This kind of candor was prized by realist critics of the common law model. See FrANK, supra note 36, at 12! ("To do their intricate job well our judges need all the clear consciousness of their purpose which they can summon to their aid.").

${ }^{149}$ Witness the Court's lengthy discussions of the proper "level of scrutiny." See, e.g., Clark v. Jeter, 486 U.S. 456, 461 (1988) (discussing, in an equal protection case, the three levels of scrutiny and noting how the application turns on the classifications made).

${ }^{150}$ I do not mean to suggest by this that courts have given up analogical reasoning; they have not. Instead, analogical reasoning has been redirected from facts and statute toward methodology. See infra Part IV (discussing the creation of categories unified by methodology). 
culture and perspective. The expectation is not the end of the case, the reasonable expectation is; scrutiny is not the finish, the level of scrutiny is. Courts still exercise normative authority, but simply do it in different rhetorical guises. They decide which expectations are reasonable or which interests are compelling or merely important. Embracing perspective as doctrine, then, means that there are some cases in which perspective does not count, where values are not relative, where courts may make "objective" judgments about reasonable expectations of privacy and compelling governmental interests.

One might argue that all of this effort serves important purposes. Professor Schauer, for example, has argued that courts should selfconsciously emulate the making of legislative rules. ${ }^{151}$ Unlike others, I have no quarrel with courts borrowing concepts or formats that seem closer to the legislative rulemaking ideal. Form is not the issue: a three-part test may be the agent of terror as easily as a one-word command. The danger here is not in courts' recognition or emulation of legislative style, but that the courts' struggle for their own identities is a rhetorical diversion-that the rhetoric of selfconsciousness will eclipse, and subvert, the real decisions that need to be made.

First, there is the danger that the rhetorical compromise between a law that defers and one that judges will be mistaken for one that has simply given up judging. Describing a "claim" as an "interest" grounds it in nature. Unlike a "claim," which is pure legal convention, an "interest" appears to exist in the world without regard to what the court does and will exist long after the court has come to its decision. This "naturalizing" of legal arguments in the world encourages deference to popular needs but risks indifference to the unpopular. A rule that encourages courts to believe that all they are doing is "describing" a world of interests and perspectives, if imposed on a world full of inequalities, will simply redescribe, and entrench, those inequalities within the law itself. ${ }^{152}$ As R.M. Hare put it, "standards only remain current when those who make judgements in accordance with them are quite sure that, whatever else they may be

${ }^{151}$ Schauer, supra note 1, at 1470 (arguing that "it may be appropriate to think of opinion writing as (at least in part) a conscious process of rule making").

${ }^{152}$ Even those sympathetic to the realist project have acknowledged this. See HORWITZ, supra note 6, at 211 (noting Fuller's criticism that "in attempting to have law simply mirror society, Realism ended up endowing the Is with normative content"). 
doing, they are evaluating (i.e. really seeking to guide conduct)."153 Nothing in the rule of perspective's future-focused gaze or its threeprong attack tells us when law should "reflect" life and when "life's inequalities" require some kind of corrective push. Indeed, it may make this choice difficult to see by wrapping all the normative decisions into the adjectives we use to describe the interests claimed.

Second, and perhaps most importantly, there is the lurking question whether all this rhetorical work will help the court decide. When courts engage in "interest-speak," they are trying to maintain an image of themselves as "realistic," but, at the same time, normatively authoritative. As Philip Bobbitt put it, "[d]octrinal argument as we know it today seeks to preserve the aesthetic of the rule of law in the new context created by realism." 154 The balance between realist critique and common law image is worked out in concepts that flip-flop between life and law, between the descriptive and the prescriptive, between interests and compelling interests. Will a search for the intensifying attributes of the interests claimed (what is compelling, what is clear, what is reasonable) tell us much about the individual or institutional consequences of the decision? Ultimately, there will be a result to these cases: the court will decide one way or another; it will either remake the decisions of legislatures or defer to political decisionmakers; it will honor the claims of social reality or brand societal ideals as prejudice. The risk here is that the rhetoric used to make these decisions does less to resolve those questions than it does to serve the institution (and to sustain its selfimage in a realist world). The risk is that, in making decisions, courts will ask questions, not about those who will have to live by their decision, but that they will ask and answer questions about its own identity.

\section{READING Constitutional CASES}

We move, finally, to the way in which constitutional cases are "read" in the modern era. The story is familiar enough: one day a judge has occasion to use an expression that involves an adjective of weight, power, strength, or direction (for example, "compelling," "hard," or "fundamental"). Upon reading this opinion, later courts seize upon the adjective and conclude that the earlier case stands for a principle that the adjective announces. Over time and repeated

${ }^{159}$ R.M. HARE, THE LANGUAGE OF MORALS 147 (corrected ed. 1972).

${ }^{154}$ BOBBITT, supra note 61 , at 42 . 
use, the chosen phrase is elevated to constitutional stardom. What is important for our purposes here is not the particular part of speech chosen, but the habit of mind and the unstated theoretical commitments that this reading entails. When lawyers transform the offhand use of an intensifying adjective (for example, "fundamental") into a category of legal significance (for example, "fundamental rights"), they perform an act of enormous legal importance that may escape careful consideration or reflection. As I hope to show, this very reading of cases reflects a response to popular critiques of more traditional common law ideals of decisionmaking.

\section{A. Making Categories}

Let us take a closer look at the typical course of one-perhaps archetypal-example of this process. During the 1960s and early 1970s, the Supreme Court announced what doctrinalists have come to call the "fundamental rights" strand of equal protection doctrine. Although the cases often dealt with very different subject matters, the word "fundamental" was quickly seized upon in law reviews and lower courts. The doctrine, as repeated, provided that litigants invoking "fundamental rights" were entitled to special protection; the government's interest, in such cases, would be strictly scrutinized. ${ }^{155}$ Some of the most difficult equal protection cases before the Court during these years-cases on race, ${ }^{156}$ voting, ${ }^{157}$ reproduction, ${ }^{158}$ and criminal procedure ${ }^{159}$-relied, at least in part, on the idea of "fundamental rights." ${ }^{160}$ It was not long, however, before scholars and doctrinalists both wondered how far the category could be stretched.

${ }^{155}$ See STONE ET AL., supra note 115, at 842 (examining the intersection of equal protection and implied fundamental rights jurisprudence).

${ }^{156}$ See, e.g., Loving v. Virginia, 388 U.S. 1 (1967) (striking down an antimiscegenation statute).

${ }^{157}$ See, e.g., Reynolds v. Sims, 377 U.S. 533 (1964) (upholding one person-one vote).

${ }^{158}$ See, e.g., Eisenstadt v. Baird, 405 U.S. 438 (1972) (striking down statute prohibiting provision of contraceptives).

${ }^{159}$ See, e.g., Douglas v. California, 372 U.S. 353 (1963) (striking down denial of right of indigent defendants to counsel on appeal).

${ }^{160}$ There were, of course, the equally controversial "fundamental rights" cases that did not explicitly invoke the Equal Protection Clause. See, e.g., Roe v. Wade, 410 U.S. 113 (1973) (abortion); Griswold v. Connecticut, 381 U.S. 479 (1965) (contraception). On the differences between the "equal protection" and "due process" strands of fundamental rights jurisprudence, $\mathrm{s} \rightarrow$ Ira C. Lupu, Untangling the Strands of the Fourteenth Amendment, 77 MICH. L. REV. 981 (1979). 
The Court ultimately called a halt ${ }^{161}$ but, in the course of the retrenchment, many came to question the original project-the doctrinal embrace of the word "fundamental." ${ }^{162}$ If treatises, case books, and scholarly articles are any measure, however, the fundamental rights strand of equal protection doctrine stuck, and stuck despite its tendency to unleash violent attacks on the Court's embrace of so-called unenumerated rights. ${ }^{163}$

How did we arrive here? If a traveler from a foreign legal culture turned to traditional legal materials governing the Equal Protection Clause, she would almost immediately be directed by the literature to Skinner v. Oklahoma. ${ }^{164}$ Casebooks and treatises tell us that Skinner stands at the base of a pyramid of ascendingly complex "fundamental rights" cases. ${ }^{165}$ In Skinner, we learn, "[t]he Court first pointed to fundamental interests in the equal protection context." treatises tell us that Skinner marked "the first time constitutional recognition of a fundamental right was held by the Supreme Court to mandate a norm of equal distribution." ${ }^{167}$

When our visiting scholar turns to the Skinner opinion itself, however, she is likely to be quite disappointed. Scanning the opening

${ }^{161}$ See, e.g., San Antonio Indep. Sch. Dist. v. Rodriguez, 411 U.S. 1 (1973) (refusing to find "education" a fundamental right necessitating strict scrutiny of differential school funding schemes).

${ }^{162}$ As Justice Harlan famously put it in Shapiro $v$. Thompson: "I must reiterate that I know of nothing which entitles this Court to pick out particular human activities, characterize them as 'fundamental,' and give them added protection under an unusually stringent equal protection test." 394 U.S. 618, 662 (1969) (Harlan, J., dissenting).

${ }^{163}$ See Robert H. Bork, The Tempting of America: The Political Seduction OF THE LAW 63-64 (1990) ("Skinner revived and remade the equal protection clause" in ways that "cannot avoid legislating" by permitting courts to decide which classifications should be treated like race).

164316 U.S. 535 (1942) (holding that a state statute providing for the sterilization of habitual criminals violates the Equal Protection Clause of the Fourteenth Amendment).

${ }^{165}$ See, e.g., STONE ET AL., supra note 115, at 842; NOWAK \& ROTUNDA, supra note $116, \S 14.27$, at 797 ("The development of the contemporary concept of a constitutionally protected 'right of privacy' in sexual matters can be traced to the Supreme Court's decision in Skinner v. Oklahoma. ... This rationale ... established the basis for 'fundamental rights' analysis under the due process and equal protection guarantees....").

${ }^{166}$ STONE ET AL., supra note 115, at 842. Thus, Supreme Court opinions discussing Skinner say things like: Skinner is among the cases that stand for the proposition that "[c]lassifications that burden, impinge or discriminate against such fundamental interests are "highly suspect."' Lindsey v. Normet, 405 U.S. 56, 82 (1972) (Douglas, J., dissenting in part).

${ }^{167}$ LaURence H. TRibe, American Constitutional Law 1463 (2d ed. 1988). 
of the opinion, she would find no reference to the term "fundamental," nor to the announced shift in doctrine predicted by the treatises. She would note that the opinion opens by emphasizing that the case "touches a sensitive and important area of human rights," involving the "right to have offspring," immediate reinforcement that the Court was forging a new rule, rather than merely making an introductory bow toward reversal. For, almost immediately after this announcement, the opinion launches into territory that seems ill-suited to express a clear break with the past. Instead, our foreign observer would read Justice Douglas's protestations that he was not departing from existing case law, ${ }^{169}$ and would note his insistence that he was giving the state the same "large deference" accorded to the Court's post-New Deal equal protection cases. $^{170}$ And as she read on, she would become convinced that Skinner is primarily occupied with distinctions that play no part in its popular history. Justice Douglas devoted most of the opinion to the claim that the statute applied to petty thieves but not to white-collar criminals. A three-time thief, Douglas wrote, may be sterilized, but an embezzler may not, a distinction repeated throughout the opinion in excruciating detail. ${ }^{171}$

${ }^{168}$ Skinner, 316 U.S. at 536.

${ }^{169}$ See id. at 540-41. In a portion of the opinion typically excised from casebooks, Justice Douglas emphasized the Court's duty of deference toward states' choices, writing:

[The states] may mark and set apart the classes and types of problems according to the needs and as dictated or suggested by experience.... [A] State is not constrained in the exercise of its police power to ignore experience which marks a class of offenders or a family of offenses for special treatment. Nor is it prevented by the equal protection clause from confining "its restrictions to those classes of cases where the need is deemed to be clearest."

Id. at 540 (quoting Miller v. Wilson, 236 U.S. 373, 384 (1915)).

${ }^{170}$ See id. at 541 ("[W]e give Oklahoma that large deference which the rule of the foregoing cases requires.”).

${ }^{171} I d$. at $538-39$ (" $[\mathrm{H}]$ e who embezzles property worth more than $\$ 20$ is guilty of a felony. A clerk who appropriates over $\$ 20$ from his employer's till and a stranger who steals the same amount are thus both guilty of felonies. If the latter repeats his act and is convicted three times, he may be sterilized. But the clerk is not subject to the pains and penalties of the Act no matter how large his embezzlements nor how frequent his convictions. A person who enters a chicken coop and steals chickens commits a felony; and he may be sterilized if he is thrice convicted. If, however, he is a bailee of the property and fraudulently appropriates it, he is an embezzler. Hence, no matter how habitual his proclivities for embezzlement are and no matter how often his conviction, he may not be sterilized." (citations omitted)). This "class" distinction is a repeated theme of Justice Douglas's opinion:

In terms of fines and imprisonment, the crimes of larceny and embezzlement rate the same under the Oklahoma code. Only when it comes to sterilization 
Only if the foreign scholar continues past the lengthy discussions about petty thieves and embezzlers, past the earlier cases and the deference to be accorded to the state, will she find the reference to "fundamental" that modern writers emphasize. Six pages into the opinion, almost at its end, she finds these words: "We are dealing here with legislation which involves one of the basic civil rights of man. Marriage and procreation are fundamental to the very existence and survival of the race." ${ }^{172}$ Here, the foreign scholar finds the doctrine of the opinion. ${ }^{173}$ Not surprisingly, she may be moved to ask why we have invested this particular passage with more importance than the rule of deference, the arbitrary criminal law distinctions, or the biologically irreparable penalty. Indeed, she may wonder why the treatises have enthroned this passage as doctrine by means of the term "fundamental rights" when the passage itself speaks of fundamentality "[ $[$ to $]$ the race." 174

If pressed, we would have to admit that Skinner might be read a number of other ways and that it might have been doctrinalized differently. We might have said that Skinner is about class distinctions in criminal law; ${ }^{175}$ we might have said that Skinner is about the imposition of irreparable biological harm. ${ }^{176}$ Indeed, I believe there is

are the pains and penalties of the law different. The equal protection clause would indeed be a formula of empty words if such conspicuously artificial lines could be drawn.

Id. at 542. "Sterilization of those who have thrice committed grand larceny, with immunity for those who are embezzlers, is a clear, pointed, unmistakable discrimination." Id. at 541. "Here there is no such saving feature. Embezzlers are forever free. Those who steal or take in other ways are not. If such a classification were permitted, the technical common law concept of a 'trespass' ... could readily become a rule of human genetics." Id. at 542 .

${ }^{172} I d$. at 541.

${ }^{178}$ See, e.g., NOWAK \& ROTUNDA, supra note 116, § 14.27, at 797 ("Despite the broad police powers of the state, this classification violated the equal protection clause because it could not withstand the scrutiny to which the fundamental nature of the right involved demanded it be subjected.").

${ }^{174}$ Skinner, 316 U.S. at 541.

${ }^{175}$ Indeed, Skinner has been read with sympathy toward this position. See TRIBE, supra note 167, at 1464-65 (noting that the Court in Skinner was not only concerned with the "right to reproduce," but also evidenced "an even greater preoccupation with the notion that the state's classifications had been promulgated with their harshest effect against a relatively powerless minority, that of lower-class, as opposed to whitecollar, criminals," a distinction that Tribe likens to "invidious or suspect classification").

${ }^{176}$ See, e.g., Skinner, 316 U.S. at 546 (Jackson, J., concurring) ("There are limits to the extent to which a legislatively represented majority may conduct biological experiments at the expense of the dignity and personality and natural powers of a minorityeven those who have been guilty of what the majority define as crimes."). 
good reason to suspect that Justice Douglas may have feared that race was a lurking issue. He may have known that the statutory term triggering sterilization, crimes of "moral turpitude," had been used to cloak efforts to control, demean, and disenfranchise AfricanAmericans. ${ }^{177}$ But, even if he did not, by 1942 Hitler had shown quite clearly how the eugenics movement, which inspired the Skinner statute, could be bent toward racist and, indeed, genocidal ends. ${ }^{178}$ In Skinner, Justice Douglas simply warned us of the racial implications of Oklahoma's statute in ways that seem oblique today, by noting the

${ }^{177}$ Several years earlier, in 1935, the Supreme Court noted the ways in which race was connected to the concept of "moral turpitude" in both the popular and legal imagination. In Norris v. Alabama, 294 U.S. 587 (1935), the Court struck down Alabama's practice of excluding blacks from juries under a statute that, among other things, barred jury service by those who had committed a "crime involving moral turpitude." In reaching its conclusion, the Court emphasized the jury commissioner's testimony that he did "not know of any negro in Morgan County over twenty-one and under sixty-five who . . has never been convicted of a crime involving moral turpitude." Id. at 598-99 (emphasis added). Decades later, the Supreme Court came to the same conclusion in Hunter $v$. Underwood, 471 U.S. 222 (1985), holding that Alabama had cloaked blatant efforts to establish "white supremacy" by disenfranchising blacks in a constitutional provision that barred voting by persons who had committed a "crime involving moral turpitude." Id. at 228-32; see also Claudia Johnson, Without Tradition and Within Reason: Judge Horton and Atticus Finch in Court, 45 AlA. L. REv. 483, 492-94 (1994) (discussing the connection between crimes of moral turpitude and exclusions of black jurors and testimony by black witnesses). If, indeed, the statutory triggering factor, "crimes of moral turpitude," was known as a potential refuge for racism, then Douglas was correct when he made his famously difficult statement that the statute's classification was as potentially "invidious" as the "select[ion of] a particular race." Skinner, 316 U.S. at 541. It would also explain why Justice Douglas seemed to rely so heavily on Yick Wo v. Hopkins, 118 U.S. 356 (1886), a case involving racial discrimination.

${ }^{178}$ The statute at issue in Skinner was passed during the heyday of the eugenics movement, a movement that spawned such overtly racist statutes as the one barring interracial marriages, struck down decades later in Loving v. Virginia, 388 U.S. 1 (1967). In America, the movement inspired dozens of state statutes aimed at protecting the public health. See Paul A. Lombardo, Medicine, Eugenics, and the Supreme Court: From Coercive Sterilization to Reproductive Freedom, 13 J. CONTEMP. HEALTH L. \& POL'Y 1, 1 (1996) ("The most powerful vehicle of the eugenic ideology was the law."). It was in this atmosphere that the Court, in Buck v. Bell, upheld the sterilization of, as Justice Holmes put it, "imbeciles." 274 U.S. 200, 207 (1927). By the time Skinner was decided in 1942, the Nazi eugenics program had been in operation for almost a decade, and had called into question the American movement's premises and racist potential. See Lombardo, supra, at 11-12. Critics of the American movement charged that it branded minorities as genetically undesirable, "socially inadequate and a constant menace to the white race and society at large." Barbara L. Bernier, Class, Race, and Poverty: Medical Technologies and Socio-Political Choices, 11 HARV. BLACKLETTER J. 115, 130 (1994) (citing Elaine Ellis, STERILIZATION: A MENACE TO THE NEGro 155 (1937)). 
power of the remedy, "[i]n evil or reckless hands," types which are inimical to the dominant group to wither and disappear." 180

Skinner has come to mean, in many ways, what later cases-cases on abortion and contraception-have required it to mean. ${ }^{181}$ The point here is not whether those later cases have interpreted Skinner correctly. ${ }^{182}$ The point is that standard doctrinal treatments have

179 Skinner, 316 U.S. at 541 . This is, most likely, a reference to Hitler. Shortly after the Skinner opinion was issued, Jewish organizations turned to Douglas to help publicize the plight of European Jews. Douglas declined until an impassioned telegram from the American Jewish Congress in February of 1943 implored him-in the name of the "two million Jews [that had] already been murdered by Hitler"-to offer his words at a Madison Square Garden rally. Telegram from Stephen S. Wise, American Jewish Congress, to William Douglas 2 (Feb. 25, 1943) (on file with Manuscript Division, Library of Congress). Douglas wrote a draft of a speech that opened dramatically: "Barbarism has no restraints. A decade ago the Nazis commenced their systematic torture of the Jews. This savagery was now spread over the continent of Europe." William O. Douglas, Radio Address from Madison Square Garden (Mar. 1, 1943) (draft on file with Manuscript Division, Library of Congress).

Douglas was also aware of the light the Nazi practices shed on American racism. One of the first letters to congratulate Douglas on his Madison Square Garden speech was from the NAACP, noting that the organization particularly appreciated Douglas's "inclusion of the reference to discrimination based on color" (a reference that does not appear in the printed speech). Letter from Walter White, Secretary, NAACP, to William O. Douglas (Mar. 5, 1943) (on file with Manuscript Division, Library of Congress).

${ }^{180}$ Skinner, 316 U.S. at 541 (emphasis added). The connection to race, eugenics, and history might have been clearer had Justice Douglas included a sentence he excised from his original draft: "The classification hardly has firmer constitutional basis than if in dealing with particular offenses it drew a line between rich and poor or between Nordic and other racial types." See William O. Douglas, Draft of Opinion in Skinner (n.d.) (unpublished draft, on file with Manuscript Division, Library of Congress) (emphasis added). Douglas substituted for this sentence a more oblique reference to the use of a rule of trespass to create "a rule of human genetics." Skinner, 316 U.S. at 542 .

${ }^{181}$ See, e.g., Roe v. Wade, 410 U.S. 113, 152 (1973) (citing Skinner with other "fundamental rights" decisions).

${ }^{182}$ There are many wise and important reasons for this modern reading, not the least of which is that it allows us to forget that, applied literally, Justice Douglas's opinion would actually constitutionalize sterilization procedures as long as they were applied evenly, across the board. As Chief Justice Stone put it in his concurring opinion: "If Oklahoma may resort generally to the sterilization of criminals ... I seriously doubt that the equal protection clause requires it to apply the measure to all criminals in the first instance, or to none." Skinner, 316 U.S. at 543 (Stone, C.J., concurring). By emphasizing the fundamental rights aspect of the case, and deemphasizing the equal protection aspect of the opinion, we harmonize the opinion in favor of our modern sensibilities that find sterilization offensive. See, e.g., Katharine T. Bartlett, Tradition, Change, and the Idea of Progress in Feminist Legal Thought, 1995 WIS. L. REV. 303, 310 \& n.28 (1995) (articulating the widely held view that Skinner is really an 
chosen to "read" the case in a particular way, remembering certain aspects and forgetting others-remembering the case for its adjectival enthusiasms rather than for its subject (criminal law), or its statute (crimes of "moral turpitude"), or the history of racist eugenics. ${ }^{183}$ This rule of doctrinal recognition is far from controversial ${ }^{184}-$ it is shared by conservatives and liberals alike; indeed, it is necessary to their battle about the "existence" of fundamental rights. ${ }^{185}$ For all intents and purposes, then, as the casebooks, treatises, and law reviews tell us, Skinner is a "fundamental rights" case. ${ }^{186}$

\section{B. Textual Anxieties}

A foreign observer, unsteeped in contemporary controversies, might note that this way of reading Skinner is far from given. Skinner could be categorized as a case about sterilization, or eugenics, or arbitrary distinctions within the criminal law. Focus might have been cast on the distinction between stealing chickens and stealing stocks, or on the history of the Court's shifting views on sterilization. ${ }^{187}$ Today, we doctrinalize Skinner with a different ideal in mind: Treatises and hornbooks find Skinner's doctrine in a bit of text reconceived as methodology. ${ }^{188}$ Not surprisingly, what most people remember about Skinner is neither its era nor its statute, but its fit within analytic structures, all summed up in Justice Douglas's

\footnotetext{
"underground" substantive due process case because its equal protection rationale seems so unappealing).

${ }^{189}$ I do not mean to suggest by this that Skinner was argued or briefed as a case involving race discrimination. See, $e \rightarrow$ Michael Klarman, An Interpretive History of Modern Equal Protection, 90 MICH. L. REV. 213, 235 n.94 (1991) (arguing that Skinner "did not (facially, at least) involve racial discrimination"). Instead, my point is that without Nazi racism raising the risk that a eugenics statute could be used to perpetuate the "dominant group," the case might well have been decided the other way, given the Court's prior holding in Buck v. Bell, 274 U.S. 200 (1927). The risk that the statutory terms themselves may also have reflected racist ideology, see supra note 177, if known, would only have reinforced fears that the statute would be put to racist ends in America.

${ }^{184}$ Typical readings of Skinner tend to reduce the opinion's "rationale" to "establish [ing] the basis for 'fundamental right' analysis under the due process and equal protection guarantees." NOWAK \& ROTUNDA, supra note 116, § 14.27, at 797.

${ }_{185}$ See BORK, supra note 163, at 63-64 (reading Skinner as a fundamental rights case, and therefore, an illegitimate exercise of judicial power).

${ }^{186}$ See supra notes 163, 165, 167 and accompanying text.

${ }_{187}$ See supra note 178 (discussing Buck v. Bell, 274 U.S. 200 (1927)).

${ }^{188}$ See supra notes $166,167,173$ and accompanying text.
} 
reference to procreation as "fundamental" to the race-transformed from a statement of fact to a statement of constitutional method.

Our reading of Skinner thus warns us almost immediately that courts' sense of their job description has changed. Once upon a time, fact and holding, rather than method, provided the organizing principle of constitutional law. Open up a constitutional law treatise of the 1890s or the 1920 s and compare that treatise to one of today: you will be stunned at the concreteness of its conceptual categories. You will find early equal protection law divided up into "Territorial Classification," "Corporations and Individuals," and "Public Utilities and Carriers," while the Commerce Clause is partitioned among "Vessels," "Regulation of Ports and Harbors," and "Pilotage," among other things. ${ }^{189}$ No common law court would have put cases about criminal appeals and marriage certificates and sterilization all in one conceptual box. Today, we do: They are called "fundamental rights" cases, $^{190}$ and they are so called, not because they share facts or holdings, but because they share a method and a peculiarly modern approach toward constitutional issues.

The tendency to read Skinner as constitutional methodology is more than simply a question of style or rhetoric-it reflects a changing image of how legal categories should be built. The term "fundamental rights" has a very rich jurisprudential meaning and a long constitutional history. ${ }^{191}$ But our modern category of "fundamental rights" differs quite substantially from earlier understandings. Today, a student who described a death penalty or takings case as a case about "fundamental rights" might fail her constitutional law exam-not because the rights to liberty and property are not fundamental in jurisprudential or other senses, but

${ }^{189}$ HenRy CAMPBell BlaCK, HaNdBOOK OF AMERICAN CONSTITUTIONAL LAW 20228, 580-85 (4th ed. 1927); see also WESTEL W. WilloughBY, PRINCIPLES OF THE CONSTITUTIONAL LAW OF THE UNITED STATES $\$ \$ 287-300$ (2d ed. 1930) (including a variety of categories under the "commerce power" including "Base Ball," "Cab Service," and "Driving Sheep across State Lines").

${ }^{190}$ The subject matter of modern "fundamental rights" cases is notoriously diverse. See supra notes 156-64 (describing cases including those concerning travel, abortion, criminal appeals, sterilization, race, marriage, voting, welfare, and contraception).

${ }^{191}$ Numerous opinions, decided long before Skinner, referred to "fundamental" rights or interests. Typically, of course, the Court was referring to property or contract rights. See, e.g., Hancock v. City of Muskogee, 250 U.S. 454, 456 (1919) ("[I]t is essential to the protection of the fundamental rights of the property owner that . . he have notice ...."); Butler v. Perry, 240 U.S. 328, 333 (1916) (noting that the Fourteenth Amendment "was intended to preserve and protect fundamental rights long recognized under the common law system"). 
because the doctrinal label would be wrong. The doctrinal label would be wrong because, in modern constitutional law, the term "fundamental rights" requires a conclusion not only that the right has a certain character and that it has triggered a similar "scrutiny" in the past, but also, crucially, that it is not specifically enumerated in the Constitution itself.

As I have said before, all this could be coincidence, but it seems difficult to believe that such a doctrine-one that openly acknowledges the dangers of judging-does not reflect a changing ideal of law and courts. The "fundamental rights" rule acknowledges not only that doctrine is "made" (out of prior texts), but also that it may as well be "made up." As every law student knows, the doctrinal category "fundamental rights" cannot be described without considering the possibility that the Court has no business identifying such rights. Indeed, casebooks introduce students to the concept by warning them that there is something false about the entire enterprise-that courts simply identify "personal freedoms and declare them "rights." "192 Indeed, without this flavor of illegitimacy, there would be little to bind "fundamental rights" cases together; the category's theory of sameness depends upon the fear of doctrinal failure.

If we can see courts' self-consciousness in the content of the category, it also emerges in the way a case like Skinner is read. Skinner becomes a case not only about the lack of constitutional text, but the increasing importance of the Court's own texts. The common law ideal imagined doctrinal rules as the distillation of precedent, transcending the words used by a court. As Judge Posner has noted, "[w]e are not afraid that we would lose the meaning of negligence if we put it in different words from those used by Learned Hand, or William Prosser, or some other authoritative expositor of the concept." ${ }^{\text {"193 }}$ By contrast, our category of fundamental rights is tied to its "particular verbal formulation." 194 To use any different adjective, or to describe the right involved at a different level of specificity, is to

${ }^{192}$ DANiEl A. FARBer ET AL., CONSTItUTIONAL LAW 381 (1993). A leading constitutional law treatise makes no bones about it: "All that can be said with certainty is that a majority of the Supreme Court Justices have selected a group of individual civil liberties which do not have a clear textual basis in the Constitution or its Amendments and declared those rights to be 'fundamental.'" NOWAK \& ROTUNDA, supra note 116, $\$ 11.7$, at 404; see also NAGEL, supra note 1, at 196 ("The principal characteristic of a fundamental interest appears to be that the Court calls the interest fundamental.").

${ }^{193}$ RiChARD A. POSNER, THE PROBLEMS OF JURISPRUdENCE 248 (1990).

${ }^{194}$ Id. 
extinguish the possibility of applying the doctrine. Indeed, if a court today were to apply the "fundamental rights" doctrine without using that particular phrase, it is doubtful that the resulting opinion would be read or classified as a "fundamental rights" case.

If one doubts that there is anything particularly "modern" about this shifting sense of the doctrinal art, all one has to do is to take the modern grammar and place it in an earlier age. For decades, the Court anchored its constitutional jurisprudence in the "police power." ${ }^{195}$ No one argued at the time (indeed, it seems almost absurd to contemplate) that we would lose the police power if it were described in any different way. The "police power" aspired to a conceptualism dependent upon a class of factual and legal circumstances in which courts would defer to the exercise of state power. ${ }^{196}$ Today, when we explain the "police power" to our students, we do not pick up the dictionary and point to the plain meaning of "police." Instead, we offer examples of cases that fall within the core meaning of the concept-examples of quarantine laws and inspection measures. We do this instinctively, unreflectively, as if we knew that the term did not obtain its meaning from the dictionary definitions of its components, but that it aspires to a conceptualism built upon an older ideal in which doctrine is something distilled, rather than expressed, in fact or holding. ${ }^{197}$

When we read a case like Skinner for its embrace of "fundamental rights," we accept a changing image of the virtues and vices of judging. In a common law world, law is both permanent and transcendent; in a modern law world, it is assumed to be both contingent and potentially illegitimate. In a common law world, authority and legitimacy depend upon courts' ability to transmit and perpetuate an unwritten tradition by marrying law and life in holdings; ${ }^{198}$ in a modern world, authority and legitimacy depend upon methodological certainty. In a common law world, where courts

${ }^{195}$ See supra note 56.

${ }^{19 \%}$ Indeed, as Morton Horwitz tells us, the "police power" derived from common law concepts. HORWITZ, supra note 6, at 28 ("During the 1870 s and 1880 s, police power analysis was regarded as largely derivable from categories developed in the common law of nuisance.").

${ }^{197}$ See Meyer, supra note 92, at 432 (noting that in this "Blackstonian tradition, because the authority of law lies outside the judge's words, opinions ... are measured against the reason and general principles that emanate from all past decisions, bound together as a coherent whole").

${ }^{198}$ See id. at 465 ("Law, from the standpoint of the common law judge, is the coherence, sense, and significance of a set of human actions."). 
imagine themselves as the conveyors of precedent, rather than the "writers" of text, categories are shaped in the image of precedent; ${ }^{199}$ in the modern world, where courts imagine themselves as text-writers, law is what courts have "said."

Here, as in my other examples, we see doctrine struggling to acknowledge its critics, but, at the same time, leaving room for more traditional ideals. Drawing boundaries like "fundamental rights" not only acknowledges critique, but also cabins it. If the "fundamental rights" cases are the ones in which courts risk "making" law illegitimately, that means that somewhere, outside the category, there are cases where a determinate, clear, constitutional text governs. In this way, the doctrine embraces the critique (potential illegitimacy) and, at the same time, holds out hope for a legitimate doctrine built upon a self-applying Constitution.

As we have seen earlier, however, there is a price to be paid for this kind of reading, a price exacted in something more than the dullness of a style that is "methodological[ly] obsess[ed]."200 Every time the Court must draw the line between the "fundamental rights" cases and others, it must not only choose sides, but must also choose between institutional ideals. When a litigant asks a court to recognize an unenumerated right, the court must not only weigh the parties' arguments and the demands of prior cases, but must also contend with the potential institutional consequences of its choice. If this choice is inevitable in some sense, the question remains whether it is best accomplished when the institutional choice is embedded within doctrine-when courts are not asking the question "how will this change our role?" or "is there another, better institution to decide

${ }^{199}$ Take, for example, the distinction between "direct" and "indirect" effects upon commerce-frequently cited as a classic example of nineteenth-century formalism, based on the case of United States v. E.C. Knight, 156 U.S. 1 (1895). If one reads carefully, the Court in E.C. Knight never set out the distinction in those terms, nor did it use such a distinction as a test or doctrinal standard. Instead the adjective "direct" served to distinguish prior holdings. See, e.g., id. at 15-16 ("In Gibbons v. Ogden, Brown $v$. Maryland, and other cases often cited, the state laws, which were held inoperative, were instances of direct interference with... interstate...commerce...."). Although our modern textual approach tends to focus us on the specific terms used"direct interference"-nineteenth-century treatises did not understand the case in these terms. E.C. Knight does not appear under a separate category for "direct" or "indirect" effects on commerce, but, instead, under the heading of an "anti-trust" case. See, e.g., WilloughBY, supra note 189, at 343-45 (discussing E.C. Knight under "AntiTrust," rather than "Commerce" heading).

${ }^{200}$ Horwitz, supra note 1 , at 99. 
this case?", but, instead, whether the case falls within the modern doctrinal category we know as "fundamental rights."

The danger here is that courts will confuse the real-life consequences of their decisions with their own institutional identity. What matters more in convincing us that Skinner was rightly decided: Justice Douglas's use of the term "fundamental," or the dangers, so apparent at the time, that the Oklahoma statute could risk the biological eradication of undesirable minorities? Modern doctrinal readings tend to steer us away from history and toward the opinion's text, telling us to "read" the case as one about "fundamental rights." This, of course, moves us quickly toward questions about judicial legitimacy and away from the lived consequences of decision. Once the label "fundamental rights" is invoked, we do not ask about the persons likely to be sterilized or their relationship to the "dominant" group; we do not ask about the institutional consequences of a ruling that would leave such decisions in the hands of legislatures. Instead, we focus on questions about the Court itself, its methods and its legitimacy.

Should Skinner arise again, I doubt seriously that the public would tolerate a court that refused to exercise judicial review to strike down a similar sterilization statute. And yet, despite this consensus, Skinner continues to draw us into bone-numbingly familiar debates about the legitimacy of judicial review. ${ }^{201}$ We are back again to a question I have asked before: whether a constitutional rhetoric that seeks to tame the Court's critics is more likely to find answers to questions about the Court than about those who must live by its decisions. The Supreme Court began this century with a constitutional arrogance we now know as "Lochner." Could all of our work against such arrogance risk a new constitutional narcissism?

\section{INSTITUTIONAL IDEALS AND THE DEMANDS OF DECISION}

These doctrinal histories are modern, not because the words that they use are peculiarly modern, not because the "layered-look" reveals a modern reverence for the bureaucratic or academic, and not because judges seek to hide the Constitution from the people. ${ }^{202}$

${ }^{201}$ See, e.g., BORK, supra note 163, at 64 (criticizing Skinner's reading of the Equal Protection Clause as starting down the road to situations where the Court "cannot avoid legislating the Justices' personal views").

${ }^{202}$ Cf. supra Part I (citing other work embracing these factors as at least a partial explanation of the formulaic quality of modern constitutional doctrine). 
These stories are modern because they reflect a distinctively modern struggle in which doctrinal argument tries to contend with a dying common law ideal.

In a sense, this should seem surprising because it reverses the traditional relationship between doctrine and theory by suggesting that theory-what we believe courts to be and doctrine to do-may become hardened within doctrinal categories. ${ }^{203}$ On the other hand, from a slightly different vantage point, it seems quite natural indeed. For, once we come to see that the identity of concepts, their sameness, "is conferred on objects by their being held in the embrace of a theoretical structure," ${ }^{204}$ it becomes easier to see how institutional ideals might become embedded within doctrine. From such a perspective, writing doctrine is not only a process of arbitrarily choosing categories, but of rewriting with each choice prevalent stories of what doctrine is and courts are.

\section{A. Langdell Redux?}

The standard understanding that modern constitutional doctrine has traded in one set of formalisms for another is correct, but incomplete. It is surely right in the sense that we have categories that look increasingly formulaic. It is also right in the sense that, for all of doctrine's supposed modern bow toward a more "realistic" outlook (its embrace of perspective, candor about its weaknesses, and unembarrassed acceptance of lawmaking), we have recreated, in many ways, the very kind of essentialist discourse that realist scholars deplored. Where we once looked for the essence of the "police power," today we look for the essence of "compelling interests." We have traded in one set of hopes of transcendence for another. Once transcendence was sought in history, stability, and stare decisis; today, it is sought in prediction, candor, and clarity of textual expression. In these senses, the classical style remains steadfastly with us, albeit wearing new armor.

Even so, the new doctrinal orthodoxy differs from the old. It is very difficult to translate our modern doctrinal grammar-turning

${ }^{203}$ If I am right, then we can expect to see this process continue as popularized versions of yesterday's academic fads become tomorrow's embedded doctrinal forms. I suspect that the "new wave" of this doctrinalism will come from law and economics. See, e.g., McCloud v. Testa, 97 F.3d 1536, 1551 (6th Cir. 1996) (borrowing the language of economics—of market failure, "collective action," and "negative externalities" -in a First Amendment patronage case).

${ }^{204}$ Douglas, supra note 15, at 59 (discussing the work of W.V. Quine). 
the "police power" into a "compelling police interest"-without realizing that something has changed. What my doctrinal histories have tried to show is that sometimes we can catch a glimpse, on the face of doctrine, of changing ideals of the institution. Those who study institutions regularly from the vantage point of a "foreigner" are well aware of the ways in which an institution's self-image is reflected in the concepts it embraces. Anthropologist Mary Douglas argues that every societal institution "needs a formula that founds its rightness in reason and in nature." ${ }^{205}$ These formulas represent a set of analogies from which the institution creates its stock concepts, the categories in which it "thinks." ${ }^{206}$ Because of the transaction costs of intellectual effort, these analogies become the "default position," resorted to without thought and even in the face of changing realities. In Douglas's terms, doctrine-in the move from the police power to clear law-reflects a shift in the structures of doctrinal legitimacy and normalcy. We have formalisms that are new, not because they are any less formal (formalism is inevitable within doctrinalism), and not because courts are trying to evade the people or have borrowed the style of academics, but because the new formalisms depend upon a different metaphor of the "natural legal order," one in which courts have given themselves permission to treat their opinions as texts, to see their job as a matter of social arbitration, to acknowledge with candor that law is uncertain.

Douglas's theory does much to explain why we have seen that doctrine both absorbs critique and then cabins it. If her theory is right, and institutions seek to mold the unpalatable into sustaining images, then that may help to explain the conflicting signals sent by modern constitutional rhetoric. If doctrine had truly sought to embrace the modernist critique-law's indeterminacy or relativity or

${ }^{205} I d$. at 45; see also id. at 112 ("Any institution that is going to keep its shape needs to gain legitimacy by distinctive grounding in nature and in reason: then it affords to its members a set of analogies with which to explore the world and with which to justify the naturalness and reasonableness of the instituted rules, and it can keep its identifiable continuing form. Any institution then starts to control the memory of its members; it causes them to forget experiences incompatible with its righteous image, and it brings to their minds events which sustain the view of nature that is complementary to itself. It provides the categories of their thought, sets the terms for selfknowledge, and fixes identities.").

${ }^{206}$ See id. at 45 (noting that "the entrenching of an institution is essentially an intellectual process"). 
social dependency-it would have had to make itself "irrelevant." Instead, it used its characteristic methods, the creation of hard-edged categories, to bound the critique. A doctrinal rhetoric of "unclear law" bows to the age's meaning skepticism but, in the end, posits that there is, somewhere, clear law to be found. ${ }^{208}$ A doctrinal rhetoric of "perspective" bows to the notion that "it is all relative," but still leaves room for courts to hold that only some perspectives-the reasonable ones-count. ${ }^{209}$ A doctrinal rhetoric of social "interests" bows to the notion that law is no longer autonomous, but still leaves enormous room for the court to define interests as fundamental or important or compelling, meanings that have no analogue outside of law. The move from critique to hard-edged category leaves space where something like the common law ideal still lives-where law can be clear, objective, and autonomous-alongside a rhetoric that is distinctly more likely to acknowledge doctrine's weaknesses.

The danger is not that modern constitutional doctrine has lost positive features of the common law ideal. (Indeed, that ideal is alive and well, and is experiencing something of a revival in academic (ircles.) $)^{210}$ The danger is that doctrine's struggle with institutional self-criticism tends to make real-life decisions dependent upon the resolution of difficult, and recurring, theoretical disputes. As Mary Douglas puts it, the natural metaphors chosen by institutions pick and choose "allies and opponents," which leads to a standard repertoire of "future relations" between the two. ${ }^{211}$ Consider the fate of the clear law rule. As we have seen, to apply the doctrine (and decide the case), the court often finds itself mired in deep and difficult theoretical questions about "what is law" and "how clear must clear be." ${ }^{212}$ The boundaries of clear law must not only do the work of decisionmaking, they must decide by trying to bound the indeterminacy critique that the doctrine assumes. Similar problems are posed by rules of perspective. To apply the doctrine, the court must not only find the relevant interests and expectations, it must adopt the proper "perspective" or "methodology" with respect to

${ }^{207}$ GILMORE, supra note 5, at 13 (enunciating the familiar scholarly critique that "the doctrine which may be found enshrined in case report and treatise is neither important nor relevant”).

${ }^{208}$ See supra Part II.

209 See supra Part III.

${ }^{210}$ See supra note 16 (noting this revival).

211 DOUGLAS, supra note 15 , at 63.

${ }^{212}$ See supra Part II. 
those social interests, a struggle that asks it to address difficult theoretical questions about whether and when law must defer to life and when it must command otherwise. ${ }^{213}$ Rules of perspective must not only help the court to decide individual cases, they must do so by bounding the critique that inspired them-by placing boundaries on the notion that the law is a matter of relativism and social deference. Finally, consider concepts such as "fundamental rights" in the equal protection context. To apply the doctrine, the court must not only struggle with the generality with which to describe the right claimed, but also with the legitimacy of judicial review itself. ${ }^{214}$ Again, this category must not only help the court to choose, it must do so by confronting the critique of judicial activism and law creation embedded within the concept. Staving off institutional criticism by incorporating that criticism within doctrine means that the doctrine will continue to generate the very theoretical controversies that inspired it-over and over again.

\section{B. The "Bony Structure" ${ }^{215}$ of Practice: The Case}

If we are truly realists, we will acknowledge that doctrine has successfully resisted the best, and most pretentious, intellectual efforts of this century by bending its critics' claims to new and formalistic ends. We will remember Karl Llewellyn's insistence that the Constitution is an institution, a practice, and a means of governing. ${ }^{216}$ We will also hear what the foreign observers have told us, that institutions "think" ideas that sustain themselves and, in doing so, inevitably seek to mold the ideas of their critics into fare more palatable to perceived institutional needs. ${ }^{217}$

If we are to avoid romantic yearnings for an earlier age, and the familiar arguments that this yearning spawns, we must understand

\footnotetext{
${ }^{213}$ See supra Part III.

${ }^{214}$ See supra Part IV.

${ }^{215}$ See TWINING, supra note 62, at 176 (quoting Karl Llewellyn).

${ }^{216}$ See Llewellyn, supra note 19 , at 17.

${ }^{217}$ One commentator notes:
}

Institutions systematically direct individual memory and channel our perceptions into forms compatible with the relations they authorize. They fix processes that are essentially dynamic, they hide their influence, and they rouse our emotions to a standardized pitch on standardized issues. Add to all this that they endow themselves with rightness and send their mutual corroboration cascading through all the levels of our information system. No wonder they easily recruit us into joining their narcissistic self-contemplation.

DOUGLAS, supra note 15 , at 92 . 
doctrine's real institutional limitations. Consider, for a moment, the site for doctrine's creation-the "case."118 Relative to other institutions, such as markets or legislatures, adjudication is a demanding institution. It requires decision at the same time it enjoins passivity. Unlike other legal institutions, such as markets or legislatures, courts typically have no choice to not decide. ${ }^{219}$ Someone will, in the end, win or lose. At the same time, courts have little power to set the agenda of their decisions. As Neil Komesar has put it, a "judge can do nothing until a litigant takes the initiative." ${ }^{220}$ It is the litigant's offering of facts and law to which the court must respond.

Faced with the imperative to decide in an atmosphere where there is little ability to control what is to be decided, courts strive mightily to control what they can - the reasons that they give for their decisions. Perhaps, then, it should not be surprising to find that the reasons often appear hard-edged and formalistic. In a sense, the only ideas that adjudication can possibly use are ideas that can be placed in the service of decision (as opposed to knowing, understanding, or reaching agreement). ${ }^{221}$ The "piled adjectives" now betray their attractiveness. The pile seems to offer a way to decide-if the law is clear, if the right is fundamental, if the perspective is reasonable, then

${ }^{218}$ However changed by modern litigation $\rightarrow$ :Abram Chayes, The Role of the Judge in Public Law Litigation, 89 HARV. L. REV. 1281 (1976) (discussing the development of public law litigatio $\rightarrow$ Abram Chayes, The Supreme Court, 1981 Term-Foreword, Public Law Litigation and the Burger Court, 96 HARV. L. REV. 4 (1982) (same), the structure of "the case" remains the dominant scene for the performance of adjudication in America.

${ }^{219}$ See, e.g., BOBBITT, supra note 14, at 183 (noting that cases "require a decision, not a calculation or an interpretation, or even a passionate conviction"); EISENBERG, supra note 100 , at 159 (noting that even when asked a novel issue, courts will not turn claimants away, telling them that because of the novelty, there was no law at the time and, therefore, the case cannot be decided); $c f$. AlEXANDER M. BICKEL, THE LEAST DANGEROUS BRANCH 111-98 (Yale Univ. Press 2d ed. 1986) (1962) (recounting ways in which courts exercise "passive" virtues to avoid decision).

${ }^{220}$ KOMESAR, supra note 21, at 128; see id. at 125 ("[J]udges are far less able to initiate decision-making than legislators. Legislators can resolve a social issue without anyone officially and formally bringing the issue to their attention.... Judges must await action brought by moving parties, often private parties.").

${ }^{221}$ This is what, in the end, distinguishes the law-talk of opinionwriting from the law-talk of legislatures. Juxtapose the Congressional Record with a Supreme Court opinion. Both "make" law, but read quite differently because the institutions demand different kinds of decisions which, in turn, lead to different decisional narratives. Legislature-talk is the talk of consensus-building; opinionwriting is the talk of choice. Self-legitimation, within the Congress, means a speech that moves the public, not one that would win a case in the Supreme Court. 
the case is "decided"-won or lost. Once the illusive legal "property" is found (the "fundamentality" of the right or the "compellingness" of the interest), the case's choice appears self-evident. (And, indeed, it is in some sense inevitable since all the normative choices have been pre-packaged into the original dispositional proposition.) ${ }^{222}$ This does not mean that the reasons announced in the opinion in fact decide cases-they may not. It does mean that doctrine's form will always be placed in the service of, and molded by, the court's need to decide.

This institutional understanding goes a long way toward explaining why the modernist critique never really had a chance to transform doctrine in any fundamental way without also changing the institutional demands of adjudication. ${ }^{223}$ It also goes a long way toward explaining why doctrine took what it did from its critics. There are plenty of critical insights that doctrine ignored: Modern doctrine does not adopt empirical tests for hypothetical verdicts; it does not announce a principle for every counter-principle (or at least it does not try to do this); and it does not preface its holdings by warning that "whatever follows is inherently political." Why not? Because to adopt any of these principles as doctrine is to undermine courts' self-perceived identity relative to other institutions. A court that decides based on the latest Gallup poll does not distinguish itself from a political consultants' committee. A court that sends hypothetical verdicts to an outside research firm does not distinguish itself from a university sociology department. A court that borrows from Jack Balkin's school of point-counterpoint ${ }^{224}$ does not distinguish itself from a debating society. Doctrine makes itself in an institutional image and it will borrow only those forms that it perceives will sustain that image.

${ }^{222} \rightarrow$ George P. Fletcher, The Right and the Reasonable, 98 HARV. L. REV. 949, 953 (1985) (arguing that the concept of the "reasonable man" packs into itself, from the start, normative decision $\rightarrow$ Mark Kelman, Interpretive Construction in the Substantive Criminal Law, 33 STAN. L. REv. 591, 596, 636-37, 645-46 (1981) (making a similar argument about prepacking in a different context). For an in-depth look at how this happens in the common law context, see Nourse, supra note 19, at 1384-89.

${ }^{223}$ Where the structure of litigation has changed, $\rightarrow$ Paul Gewirtz, Remedies and Resistance, 92 YALE L.J. 585 (1983), doctrine has had to make enormous strides to keep up.

${ }^{224}$ See J. M. Balkin, The Crystalline Structure of Legal Thought, 39 RUTGERS L. REV. 1, 3 (1986) (arguing that legal thinking should be "viewed dialectically as a continuing series of struggles between various sets of opposed ideas"). 


\section{A "Living Doctrine"}

Our best hope of resisting the standard arguments and replies may simply be to accept the institutional reality. Let us embrace the embarrassing and recognize that formalism will remain as long as the institutional realities of the case remain the same and that rhetoric alone cannot do away with the "requirement of a decision." ${ }^{225}$ Let us focus on the ways in which doctrine "lives" in the world. The greater danger is not that the Court is boring or impenetrable, but that its decisions forsake "lived relations" for institutional purity. Our categories must aspire to a more modest, and therefore more helpful, image-an image that is incremental and dynamic, one in which doctrine aspires to recognize that every category reflects a judgment of alternatives about a set of relationships, relationships between the Court's past and its future, between the litigants themselves, and between the Court and other institutional decisionmakers.

The realists' own philosophical patron saint, John Dewey, laid the groundwork for a dynamic understanding of legal relationships when he urged that we temper our search for knowledge built on description. In his book, How We Think, Dewey contrasts two kinds of conceptual knowledge. ${ }^{226}$ The first is dispositional. When asked to describe "metal," we offer properties or qualities of metal: "[s]moothness, hardness, glossiness, and brilliancy."227 Dewey contrasts this understanding with one in which metal is not defined by its properties, but through its chemical relationships and "interaction in constituting other substances." 228 He urges that "our conceptions attain a maximum of definite individuality" if "they show how things depend upon one another or influence one another, instead of expressing the qualities that objects possess statically."229 Metal is no longer defined by brittleness, but as "any chemical element that enters into combination with oxygen so as to form a base." 230 Dewey concludes by claiming that such knowledge allows us to "lay hold of the dynamic ties that hold things together in a continuously changing process." ${ }^{231}$

\footnotetext{
${ }^{225}$ BOBBITT, supra note 14 , at 39 (emphasis omitted).

${ }^{226}$ JOHN DEWEY, HOW WE THINK 131-34 (1910).

${ }^{227}$ Id. at 133 .

${ }^{228}$ Id. at 134 .

${ }^{229} \mathrm{Id}$.

${ }^{230} I d$.

${ }^{231} I d$.
} 
One need not embrace Dewey's hope for a science of relational understandings $^{232}$ to see that his analysis holds out hope that we may cultivate intellectual habits that strive toward understanding the dynamic relationships that bind us together. We have all had experiences similar to sitting in an optician's chair and "knowing" whether lens number one is "better or worse" than lens number two without having the vaguest idea about how the images differ optically. Litigation suffers from similar limitations. Sometimes it is far easier to decide whether claim number one or claim number two presents a better relationship between the parties, a better relationship to the court's prior decisions and its future ones, and a better relationship between courts and other legal institutions, ${ }^{233}$ than it is to articulate the essential differences between the claims. Should we give up making the right decision simply because we do not know the precise measurements that make the decision right, even if our reasons, however inarticulate, are good enough to choose among alternatives and thus to "live by"? Or should we simply recognize that, if courts fail in their obligation to articulate reasons, this failure may be corrected over time, while a failure to make the right decision could force people to live in ways that are far from easily repaired?

${ }^{232}$ The skeptic in us all will hesitate at this point and argue that all relationships can be redescribed as dispositions. That is true, but it does not eliminate the possibility that some ways of thinking may be more "dynamic" than others. Asking whether and how the law should regulate the relationship between state and citizen is a different question than asking whether certain "fundamental rights" should be protected. The former question suggests an intellectual operation in which we "value," "create," or "imagine" the relationship; the latter suggests a search for a legal object with a particular property. To the extent the latter seems to suggest that there is something to be found, it invites a backward-looking search for something "prior"whether it is a legal concept or a meaning. To the extent the former seems to suggest that we need to "create" this relationship, it sends our search in the opposite direction, inviting engagement and commitment.

${ }^{238}$ This focus on "relational" understandings is precisely what the modern doctrinal grammar tends to resist. The three-prong test actually fragments the key relational questions by drawing our attention first to one side of the case, then to the other, leaving the "relational" elements to be summed up in the amorphous and ubiquitous "nexus requirement." Moreover, the focus on textual expression tends to turn our attention to the court's own language rather than the parties' dispute, placing the judges-not the parties-at the center of the legal universe. Finally, the law's self-consciousness of its own creation tends to obscure doctrine's understanding of its relationship with the past, veiling analogy's modest virtues with a heavy-lidded textuality. Gone from view is the overarching question of the state's relationship to its citizens; instead, the only relationship we are likely to see is the relationship of an object and its attributes - of a law to its clarity, of rights to their fundamentality, or of the parties to their expectations. 
I am not arguing that we should not care about the reasons courts give, but only that a methodological focus may strike an unhealthy balance between rhetoric and result. To press formalism toward a modest dynamism requires a doctrine placed in the service of those for whom doctrine must work, not to assuage judges' or scholars' fears, but the fears of the parties and the rest of us who must live by it. In Charles Dickens's Hard Times, ${ }^{234}$ Gradgrind asked his pupil Bitzer to define "horse." Bitzer responded: "Quadruped. Gramnivorous. Forty teeth, namely twenty-four grinders, four eye-teeth, and twelve incisive. Sheds coat in the spring; in marshy countries sheds hoofs too. Hoofs hard, but requiring to be shod with iron." "Now," says Gradgrind to the pupil he calls "girl number twenty," "[y]ou know what a horse is." ever rode a 'gramnivorous quadruped," "[n]o gambler ever bet on one," and "[n]o sculptor ever 'dreamed one out of stone." "236 The people who must use the horse-for their art, for their vice, or simply for transportation-are "involved in a living relation to a living animal," and that relation will be reflected in the categories they use to describe the animal. ${ }^{237}$ Lest constitutional courts become Gradgrindian, they should be careful to remember that doctrine serves to guide action in the world, not the other way around.

Consider what might have been the doctrine of Skinner ${ }^{238}$ if the Court had asked whether the Constitution would permit a lived relationship of the kind the state sought-if it would permit a majority to threaten the biological eradication of an undesirable minority. Consider how we might have understood Skinner's relationship to the Court's past holdings if the Court had more openly acknowledged that Nazi experimentation had called into question the eugenic assumptions of Buck $v$. Bell. ${ }^{239}$ Or consider how we might have appreciated the Court's exercise of judicial power if the Court had justified its assertion of power by noting that the alternative-leaving the question to the political departments-posed greater dangers, dangers that had ended, already, in world war. Even if these are contested judgments, they are lived ones, far richer than the offhand phrases with which Skinner is now associated.

${ }^{234}$ CHARLES DiCKENS, HARD TIMES (Oxford Univ. Press 1955) (1854).

${ }^{235} I d$. at 5.

${ }^{236}$ JOHN CiaRdi \& Miller Williams, How Does A POEm MEAN? 1 (2d ed. 1975).

${ }^{237}$ Id. at 2.

${ }^{238} 316$ U.S. 535 (1942).

${ }^{299} 274$ U.S. 200 (1927). 
Appreciating the real institutional limits of doctrine is not a matter of resignation, but a moral consideration in and of itself. ${ }^{240}$ Doctrine's words "are not just for fun and mental exercise." may misuse the word "mere" and be branded a failure, and a scientist may misinterpret the word "mere" and be decried as unintelligible, but whether and how a jury hears the word "mere" may mean, quite literally, someone's life. ${ }^{242}$ We need to appreciate that "[w]ords cannot be isolated from the deeds they perform... [n]ot only because they represent or reflect on actions but because they themselves, literally, are actions." ${ }^{243}$ Even if we know that the line between politics and law is far from clear, we must remember that "[i]t is institutions which validate the Words, not the Words which validate the institutions." ${ }^{24}$ In the end, I think it takes a foreigner to our doctrinal culture to remind us that " $[t]$ he most profound decisions about justice are not made by individuals as such, but by individuals thinking within and on behalf of institutions. ${ }^{245}$

${ }^{240}$ See Hans-GeOrg Gadamer, Truth AND Method 281 (Crossroad 1986) (1975) (recounting the Aristotelian idea that "knowledge of a dynamic kind" is knowledge with a "purpose" to "determine and guide action").

${ }^{241}$ Thomas C. Grey, The Uses of an Unwritten Constitution, 64 CHI.-KENT L. REV. 211, 215 (1988); see $\rightarrow \rightarrow$ Robert M. Cover, Violence and the Word, 95 YALE L.J. 1601 (1986) (discussing how the legal interpretation of an act leads to punishment, violence, and pain).

${ }^{242}$ See LaWrence M. Solan, The Language of Judges 56-59 (1993) (discussing the degree to which the Supreme Court's decision in a death penalty case depended upon its interpretation of the term "mere" in a "mere sympathy" jury instruction).

${ }^{243}$ PAUl DE MAN, Shelley Disfigured, in THE RHETORIC OF ROMANTICISM 93, 102-03 (1984), quoted in Adam Thurschwell, Reading the Law, in THE RHETORIC OF LAW, supra note 43 , at 275,304 .

${ }^{244}$ Llewellyn, supra note 19 , at 17.

${ }^{245}$ DougLaS, supra note 15 , at 124. 